\title{
Abolishing the Excited Utterance Exception to the Rule Against Hearsay
}

\author{
Alan G. Williams ${ }^{*}$
}

\section{INTRODUCTION}

"Major Strasser has been shot . . round up the usual suspects!",

Seconds after witnessing Rick Blaine shoot and kill a Nazi officer, Captain Louis Renault utters a lie that absolves Blaine of guilt and sends the murder investigation in another direction. ${ }^{2}$ And, in Blaine's trial for the murder of Major Strasser, Captain Renault's excited utterance that someone other than Blaine was the killer would be admitted-pursuant to the Federal Rules of Evidence-as proof that Blaine did not shoot Major Strasser, regardless whether Captain Renault testified at trial.

Renowned Seventh Circuit Court of Appeals Judge Richard Posner ${ }^{3}$ recently questioned the efficacy of the excited utterance exception to the rule against hearsay, ${ }^{4}$ and called for changes to the manner in which the excited utterance exception and other hearsay exceptions are applied. ${ }^{5}$

\footnotetext{
${ }^{*}$ Professor of Law, Florida Coastal School of Law. The author wishes to thank Charles W. Ehrhardt, Robert E. Atkinson, Jr., Nat S. Stern, Daniel F. Beasley, and Henry Burnett.

1. CASABLANCA (Warner Brothers 1942). Just before Rick Blaine-played by Humphrey Bogart in the film - shoots Major Strasser, Blaine threatened to kill Captain Renault by shooting him. Whether the requisite "exciting event" is Blaine threatening Captain Renault's life or Blaine killing Major Strasser, or both, undoubtedly the court would rule Captain Renault's statement an excited utterance.

2. Id.

3. Judge Posner - the most cited legal scholar of the twentieth century - is regarded by many as America's foremost living jurist. Fred R. Shapiro, Most Cited Scholars, 29 J. LEgAL StUD. 409, 424 tbl. 6 (2000).

4. FED. R. EvID. 803(2). The excited utterance exception is the second most popular hearsay exception of the twenty-three enumerated exceptions in Rule 803, at least within the last year. From April 2013 to April 2014, there were 571 reported state and federal cases involving the question of whether an excited utterance may be admitted as a hearsay exception. In that same time period, 602 state and federal cases regarding the business records exception were reported, and only 157 present sense impression cases were reported. Since 2000, there have been 8,268 reported cases involving the excited utterance in the federal and state court systems. To reach these conclusions, the author researched and reviewed cases in the Westlaw database.

5. United States v. Boyce, 742 F.3d 792, 799-803 (7th Cir. 2014) (Posner, J., concurring), cert. denied, 134 S. Ct. 2321 (2014).
} 
This Article attempts to expound on Judge Posner's critique of the excited utterance exception and proposes a new rule of admissibility to remedy the excited utterance exception's current flaws.

\section{HEARSAY, RES GESTAE, AND THE EXCITED UTTERANCE EXCEPTION}

\section{A. The Rule against Hearsay: Beginnings}

At its inception, the English jury system desired to seat as jurors only those community members who possessed personal knowledge regarding the facts of the case who then were expected to undertake their own investigation into the case, ${ }^{6}$ but by the seventeenth century English juries essentially became comprised of what we attempt to achieve today: an impartial group of citizens with no prior knowledge of the case that hears evidence presented by the opposing attorneys and then makes a just determination based on the facts presented at trial. ${ }^{7}$ Since jurors were no longer expected to rely on their own information and investigation regarding the case, what the attorneys presented as evidence became paramount. Distrust of jurors and their ability to appropriately weigh the credibility of a witness's trial testimony recounting someone else's statement resulted in the rule against hearsay: ${ }^{8}$ an out-of-court statement, whether written or oral, offered for the truth asserted in that statement is inadmissible. ${ }^{9}$

Borrowing from the English fear that juries might decide cases, in whole or in part, premised on gossip or second-hand information not subjected to cross-examination ${ }^{10}$ were such evidence admitted at trial, ${ }^{11}$

6. See, e.g., John Marshall Mitnick, From Neighbor-Witness to Judge of Proofs: The Transformation of the English Civil Juror, 32 AM. J. LEGAL HIST. 201, 203-04 (1988).

7. See, e.g., id. at 205.

8. See, e.g., Roger Park, A Subject Matter Approach to Hearsay Reform, 86 Mich. L. ReV. 51, $60 \&$ n.37 (1987) (citing Albert SHerman Osborn, THE Mind of the JuROR AS Judge OF THE FACTS, OR, THE LAYMAN'S VIEW OF THE LAW 51-52 (1937)) ("Yet, because of distrust of juries-a belief that jurors lack the competence to make allowance for the second-hand character of hearsaysuch evidence, although accepted by administrative agencies, juvenile courts and legislative committees, is (subject, to be sure, to numerous exceptions) barred in jury trials." (quoting JEROME Frank, COURTS ON TRIAL: MYTH AND REALITY IN AMERICAN JUSTICE 123 (1949))); Eleanor Swift, Abolishing the Hearsay Rule, 75 CALIF. L. REV. 495, 495-96 (1987) (stating that many scholars are critical of the rule against hearsay but also "are unwilling to risk requiring judges to defer entirely to the jury in evaluating the reliability of hearsay declarants").

9. FED. R. EvID. 801.

10. Cross-examination "has always been regarded as the greatest safeguard of American trial procedure." United States v. Inadi, 475 U.S. 387, 410 (1986) (Marshall, J., dissenting) (quoting New York Life Ins. Co. v. Taylor, 147 F.2d 297, 305 (D.C. Cir. 1945)). The Minnesota Supreme Court 


\section{American common law followed the English model and created a rule against hearsay disallowing out-of-court statements offered for their truth. $^{12}$ Basically, hearsay is inherently unreliable because it cannot be}

has concluded that " $[t]$ he chief merit of cross examination is not that at some future time it gives the party opponent the right to dissect adverse testimony. Its principal virtue is in its immediate application of the testing process. Its strokes fall while the iron is hot." State v. Saporen, 285 N.W. 898, 901 (Minn. 1939). Early legal commentators also weighed in, calling cross-examination "the most perfect and effectual system for the unraveling of falsehood ever devised by the ingenuity of mortals." Of the Disqualification of Parties as Witnesses, 5 AM. Legal Reg. 257, 263-64 (1857). Professor John Henry Wigmore - one of America's first and most notable evidence scholarspenned the immortal phrase that cross-examination is "beyond any doubt the greatest legal engine ever invented for the discovery of the truth." 5 JOHN HENRY WigMORE, EVIDENCE IN TRIALS AT COMMON LAW $§ 1367$ (James H. Chadbourn ed., 1974). However, even Wigmore allowed that some hearsay must be admitted despite not being subjected to cross-examination:

No one could defend a rule that pronounced that all statements thus untested are worthless, for all historical truth is based on un-cross-examined assertions and every day's experience of life gives denial to such an exaggeration. What the hearsay rule implies - with profound verity - is that all testimonial assertions ought to be tested by cross-examination, as the best attainable measure, and the rule should not be burdened with the pedantic implication that assertions must be rejected as worthless if the test is unavailable.

1 John Henry Wigmore, Evidence in Trials at Common LaW § 8c (Peter Tillers ed., 1983).

11. The 1603 treason trial of Sir Walter Raleigh provides one of the earliest examples why the English legal system became suspicious of hearsay, and why English evidentiary law developed a rule against the admission of hearsay. 1 THE SOCIETY FOR THE DifFUSION OF USEFUL KNOWLEDGE, CRIMINAL TRIALS 400-76 (1822). Raleigh was convicted and sentenced to death pursuant to the oral hearsay evidence of one witness (Dyer, testifying to the alleged hearsay statements of an unnamed Portuguese man) and the written hearsay evidence of another (Lord Cobham). Id. at 434-36, 45152. Raleigh pleaded, to no avail, to cross-examine the witnesses against him instead of allowing the hearsay evidence to stand untested: "Good my Lords, let my accuser come face to face and be deposed. Were the case but for a small copyhold, you would have witnesses or good proof to lead the jury to a verdict; and I am here for my life!" Id. at 427.

12. Queen v. Hepburn, 11 U.S. (7 Cranch) 290, 295 (1813). Over two hundred years ago, United States Supreme Court Chief Justice John Marshall noted that:

'hearsay' evidence is in its own nature inadmissible. That this species of testimony supposes some better testimony which might be adduced in the particular case, is not the sole ground of its exclusion. Its intrinsic weakness, its incompetency to satisfy the mind of the existence of the fact, and the frauds which might be practiced under its cover, combine to support the rule that hearsay evidence is totally inadmissible.

Id. at 295-96.

Early legal commentators also weighed in on the problem of admitting hearsay: "the reason of the rule is, because evidence ought to be given under the sanction of an oath, and that the person, who is to be affected by the evidence, may have an opportunity of interrogating the witness ..." $1 \mathrm{~S}$. M. Phillipps, A Treatise on the Law of Evidence 173 (John A. Dunlap ed., 1st Am. ed. 1816). Judge Posner wrote in United States v. Boyce that "[o]ne reason that hearsay normally is inadmissible ... is that it often is no better than rumor or gossip, and another, which is closely related, is that it can't be tested by cross-examination of its author." 742 F.3d 792, 800 (7th Cir. 2014) (Posner, J., concurring), cert. denied, 134 S. Ct. 2321 (2014). 
adequately probed and tested through cross-examination. ${ }^{13}$ However, if the ultimate goal of justice is divining the truth, and if admitting certain evidence furthers that goal, then, as long as that evidence is reliable, the common law recognized such evidence should be admitted. Thus, by the early 1800 s, a plurality of courts began acknowledging exceptions to the rule against hearsay ${ }^{14}$ because some out-of-court statements were thought to contain sufficient indicia of reliability to deem them worthy of admission into evidence: ${ }^{15}$ such exceptions were initially termed "res gestae."16

13. See, e.g., Donnelly v. United States, 228 U.S. 243, 273 (1913); 5 WIGMORE, supra note 10, at $\S \S 1362,1363$. In Donnelly, the Court explained that:

The chief grounds of [hearsay evidence's] exclusion are, that the reported declaration (if in fact made) is made without the sanction of an oath, with no responsibility on the part of the declarant for error or falsification, without opportunity for the court, jury, or parties to observe the demeanor and temperament of the witness, and to search his motives and test his accuracy and veracity by cross-examination, these being most important safeguards of the truth where a witness testifies in person, and as of his own knowledge; and, moreover, he who swears in court to the extrajudicial declaration does so (especially where the alleged declarant is dead) free from the embarrassment of present contradiction, and with little or no danger of successful prosecution for perjury. It is commonly recognized that this double relaxation of the ordinary safeguards must very greatly multiply the probabilities of error, and that hearsay evidence is an unsafe reliance in a court of justice.

Donnelly, 228 U.S. at 273 (emphasis added).

14. For decades, however, legal scholars have derided American hearsay law as a "monstrosity: a tissue of doctrine that seems to function best when it is most transparent- that is, when it is essentially ignored." Laurence H. Tribe, Triangulating Hearsay, 87 HARV. L. REV. 957, 957 (1974) (citing Edward W. Cleary, Evidence as a Problem in Communicating, 5 VAND. L. ReV. 277, 277 (1952)). Although Cleary was writing about evidence law in general, Professor Tribe opined that Cleary's "observation may be most truly applicable to the hearsay rule and its exceptions." Id.

15. See, e.g., Aviva Orenstein, "My God!": A Feminist Critique of the Excited Utterance Exception to the Hearsay Rule, 85 CALIF. L. REV. 159, 168 (1997) ("[T] excited utterance is justified by the purported trustworthiness of such statements.").

16. Res gestae "literally means "things done." Id. Legally, the term res gestae refers to "words spoken, thoughts expressed, and gestures made... [sic] so closely connected to occurrence or event in both time and substance as to be part of the happening." Id. at n.19 (quoting BLACK's LAW DICTIONARY 1305 (6th ed. 1990)). In the early 1800s, prior to hearsay doctrine being fully developed and its exceptions well defined, the term res gestae came into common legal usage "as a convenient vehicle for escape from the hearsay rule." KENNETH S. BROUN ET AL., MCCORMICK ON EVIDENCE $\S 288$ (Edward W. Cleary ed., 3d ed. 1984). The term and its relationship to hearsay have been under fire for over a century. See, e.g., James B. Thayer, Bedingfield's Case-Declarations as a Part of the Res Gesta, 14 AM. L. REV. 817, 827 (1880) ("A term that cannot be defined should be dropped."); Edmund M. Morgan, A Suggested Classification of Utterances Admissible as Res Gestae, 31 YALE L.J. 229, 229 (1922). Morgan explained that:

The marvelous capacity of a Latin phrase to serve as a substitute for reasoning, and the confusion of thought inevitably accompanying the use of inaccurate terminology, are 
The res gestae exceptions ${ }^{17}$ flowed from the concept that statements made during a legally relevant act were, in essence, part of that act and therefore should be admissible to explain the act. ${ }^{18}$ The original res gestae exceptions ${ }^{19}$ are generally considered to have included variations of the verbal acts doctrine, ${ }^{20}$ the dying declaration, a statement regarding state of mind or bodily condition, and a hybrid of the excited utterance and present sense impression. ${ }^{21}$ By definition, these res gestae

nowhere better illustrated than in the decisions dealing with the admissibility of evidence as 'res gestae.' It is probable that this troublesome expression owes its existence and persistence in our law of evidence to an inclination of judges and lawyers to avoid the toilsome exertion of exact analysis and precise thinking.

Morgan, supra, at 229. The term res gestae possesses an alternate meaning in the law-the circumstances surrounding or closely related to a relevant event. See, e.g., Proprietors of Charles River Bridge v. Proprietors of Warren Bridge, 36 U.S. 420, 469 (1837). However, for purposes of this Article, the term is employed solely to describe such aforementioned hearsay exceptions.

17. The Federal Rules of Evidence do not formally recognize res gestae as an exception to the rule against hearsay; rather, based on specific principles, the Rules allow enumerated hearsay exceptions, some of which were encompassed within the original res gestae exceptions. See, e.g., Michael H. Graham, HandBooK of Federal Evidence $\S$ 803:2 (2012) ("Under the Federal Rules of Evidence reference to the common law concept of res gestae is improper and should be avoided.").

18. See, e.g., Travellers' Ins. Co. of Chicago v. Mosley, 75 U.S. 397, 408 (1869); Colin Miller, A Shock to the System: Analyzing the Conflict Among Courts Over Whether and When Excited Utterances May Follow Subsequent Startling Occurrences in Rape and Sexual Assault Cases, 12 WM. \& MARY J. WOMEN \& L. 49, 54 (2005) ("Courts allowed these statements to be admitted despite the rule against hearsay because they believed that the statements constituted 'the automatic and undersigned incidents of the particular act in issue...." (quoting Keefe v. State, 72 P.2d 425, 427 (Ariz. 1937))). In Mosley, the Court instructed that:

In the complexity of human affairs, what is done and what is said are often so related that neither can be detached without leaving the residue fragmentary and distroted [sic]. There may be fraud and falsehood as to both; but there is no ground of objection to one that does not exist equally as to the other. . . . The tendency of recent adjudications is to extend rather than to narrow, the scope of the [res gestae] doctrine. Rightly guarded in its practical application, there is no principle in the law of evidence more safe in its results. There is none which rests on a more solied [sic] basis of reason and authority.

Mosley, 75 U.S. at 408.

19. See supra note 17.

20. Pursuant to the Federal Rules of Evidence, verbal acts are no longer considered hearsay and thus are admissible on their own without the need to employ a hearsay exception. FED. R. EVID. 801 advisory committee's note.

21. See James Donald Moorehead, Compromising the Hearsay Rule: The Fallacy of Res Gestae Reliability, 29 LOY. L.A. L. REV. 203, 203-04 (1995). Although championed by Thayer and Morgan, Wigmore abhorred the present sense impression as unreliable, as did the organized bar. See, e.g., Douglas D. McFarland, Present Sense Impressions Cannot Live in the Past, 28 FLA. ST. U. L. REV. 907, 911-12 (2001) (citing Edward J. Imwinkelried, The Importance of the Memory Factor in Analyzing the Reliability of Hearsay Testimony: A Lesson Slowly Learnt-and Quickly Forgotten, 41 U. Fla. L. REV. 215, 231 \& nn.145-47 (1989)). Congress eventually sided with Thayer and Morgan - at least for purposes of even including the exception within the Federal Rules of Evidence 
statements were uttered while the act was occurring, and thus English courts required contemporaneity for the statements to be admissible. However, early American legal commentators such as Professor John Henry Wigmore- "who is generally credited with first articulating the excited utterance exception" 22 - derided the contemporaneity requirement of the present sense impression, instead championing the excited utterance and its perceived reliability based on the alleged accuracy and truthfulness of statements uttered while still under the stress of an exciting event despite even a significant time lapse between event and statement. ${ }^{23}$ Once American jurisprudence began fully evolving (and prodded by Wigmore's influential analysis), "precise

-and enacted the present sense impression as the first enumerated exception in Rule 803. Id. at 912. Originally, statements made during an exciting event were the only ones admissible as the exception commonly referred to as a "spontaneous declaration." White v. Illinois, 502 U.S. 346, 355 \& n.8 (1992). The first recorded case of this hybrid of the present sense impression/excited utterance was in the 1694 English case of Thompson v. Trevanion, where the court admitted the hearsay statement because it was made before the declarant "had time to devise or contrive any thing [sic] for her own advantage." (1694) 90 Eng. Rep. 179, 179 (K.B.). English courts continued to favor the exception, reasoning that these of type statements "shew [the declarant's] credit and the accuracy of her recollection." Regina v. Megson, (1840) 173 Eng. Rep. 894, 895 (K.B.). It was Wigmore who drew the exception away from contemporaneity and toward stress caused by the exciting event; Thayer and Morgan preferred contemporaneity while cautioning against the risks of stress-induced statements made after an event. McFarland, supra, at 908-09. Wigmore won the battle, and ever since the excited utterance has inhabited much higher placement than the present sense impression. $I d$. at 909.

22. Jeffrey S. Siegel, Timing Isn't Everything: Massachusetts' Expansion of the Excited Utterance Exception in Severe Criminal Cases, 79 B.U. L. Rev. 1241, 1250 (1999) (citing Orenstein, supra note 15 , at 169 ).

23. 6 John Henry Wigmore, Evidence in Trials at Common LaW $\S 1750$ (James H. Chadbourn ed., 1976). Wigmore stated that:

[T] he statements need not be strictly contemporaneous with the exciting cause; they may be subsequent to it, provided there has not been time for the exciting influence to lose its sway and to be dissipated. [It is a] fallacy, formerly entertained by a few courts, that the utterance must be strictly contemporaneous.... [T]here can be no definite and fixed limit of time. Each case must depend upon its own circumstances.

Id. Thus, "Wigmore famously stalled judicial acceptance of the [present sense impression] exception for decades," in favor of the excited utterance exception. Jeffrey Bellin, Facebook, Twitter, and the Uncertain Future of Present Sense Impressions, 160 U. PA. L. REV. 331, 336-37 (2012) (citing EdMund M. Morgan, Basic Problems of Evidence 342 (1962); 6 Wigmore, supra, at $\S 1757$; Edward J. Imwinkelried, The Need to Resurrect the Present Sense Impression Hearsay Exception: A Relapse in Hearsay Policy, 52 How. L.J. 319, 327-28 (2009) ("By and large, the courts found Wigmore's position persuasive. Until the adoption of the Federal Rules of Evidence, only a few jurisdictions recognized the present sense impression.")); see also State v. Carpenter, 773 S.W.2d 1, 9 n.3 (Tenn. Crim. App. 1989) ("The present sense impression exception, although embraced by the Federal Rules of Evidence, has been criticized by authorities as having virtually no indicium of reliability."), aff'd, 126 S.W.3d 879 (Tenn. 2004). 
contemporaneousness was not required" 24 and the focus became the circumstances under which the statement was uttered. ${ }^{25}$ Therefore, what we now call the present sense impression-a narrow hearsay exception that requires near strict contemporaneity - receded in favor of the excited utterance, a broader hearsay exception that does not require contemporaneity. ${ }^{26}$ Many able commentators have written extensively on the other res gestae exceptions, especially the present sense impression ${ }^{27}$ this Article focuses exclusively on the excited utterance exception. $^{28}$

24. See, e.g., Orenstein, supra note 15, at 171, 173 ("Wigmore's insistence on the abandonment of any contemporaneousness requirement fashioned the current doctrine."); Siegel, supra note 22, at 1242 ("Over the course of two centuries, the excited utterance doctrine has evolved from the concept of res gestae, requiring simultaneity between the underlying event and the descriptive statement, to virtually abandoning a temporal requirement between the event and the statement.").

25. See, e.g., Richard D. Friedman \& Bridget McCormack, Dial-In Testimony, 150 U. PA. L. REV. 1171, 1178-79 (2002) ("This exception is based on the idea that if the declarant is speaking while still under the stress of excitement caused by a startling event or condition, she presumably has not had the opportunity to concoct a false account.").

26. Modern courts have taken Wigmore's admonition to heart, concluding that statements made several hours - or even several days - after a startling event may nonetheless be admissible under the excited utterance exception. See, e.g., State v. Young, 756 S.E.2d 768, 786 (N.C. Ct. App. 2014) (statements made six days after startling event admissible as excited utterances); In re C.C., Nos. 88320, 88321, 2007 WL 1366431, at*7 (Ohio Ct. App. May 10, 2007) (statements made 27 days after startling event admissible as excited utterances); Apolinar v. Texas, 155 S.W.3d 184, 19091 (Tex. Crim. App. 2005) (statements made four days after startling event admissible as excited utterances); State v. Duke, No. 52604, 1988 WL 88862, at *4 (Ohio Ct. App. Aug. 25, 1988) (statements made 10 days after startling event admissible as excited utterances); State v. Padilla, 329 N.W.2d 263, 267 (Wis. Ct. App. 1982) (statements made three days after startling event admissible as excited utterances).

27. See, e.g., Bellin, supra note 23; Teree E. Foster, Present Sense Impressions: An Analysis and a Proposal, 10 LOY. U. CHI. L.J. 299 (1979); McFarland, supra note 21; Moorehead, supra note 21; Liesa L. Richter, Don't Just Do Something!: E-Hearsay, the Present Sense Impression, and the Case for Caution in the Rulemaking Process, 61 AM. U. L. REV. 1657 (2012); John R. Waltz, The Present Sense Impression Exception to the Rule Against Hearsay: Origins and Attributes, 66 IowA L. REV. 869 (1981); Kathryn E. Wohlsen, The Present Sense Impression Exception to the Hearsay Rule: Federal Rule of Evidence 803(1), 81 DicK. L. REv. 347 (1977).

28. See infra Part III.A. (explaining the excited utterance exception in comparison with the present sense impression). 


\section{B. A Brief History of the Excited Utterance ${ }^{29}$ Exception}

Mary stands on a street corner facing east. She hears a terrible crash from the west followed by a man shouting, "Oh, my God! That truck just plowed into the minivan!" Mary turns west and sees two mangled vehicles intertwined amidst smoke and fire. Years later at the trial of the tort claim brought by survivors of the minivan alleging negligence against the truck driver and his employer, the plaintiff calls Mary to the stand, who testifies she did not see what caused the crash but that she heard a man - an unidentified bystander ${ }^{30}$ - shout that the truck caused the crash. The defense attorney does not even object to this hearsay testimony because she knows the rules of evidence allow Mary to recount for the jury the "excited utterance" made by the unidentified bystander, ${ }^{31}$ whether or not the bystander is available to testify at trial, ${ }^{32}$

29. Wigmore and other early commentators employed the term "spontaneous exclamation" rather than "excited utterance." Robert M. Hutchins \& Donald Slesinger, Some Observations on the Law of Evidence, 28 Colum. L. REV. 432, 432 \& nn.2-3 (1928). In the 1920s, Yale Law School Dean Robert M. Hutchins - together with psychologist Donald Slesinger-wrote a series of influential law review articles regarding evidence law, one of which noted that "spontaneous exclamations" are not "an act of pure free will, stimulated by nothing, created out of the air" but rather represent "an act so dominated by considerations external to the self, that rational thought or personal will plays no part." Id. at 432 n.2.

30. The Federal Rules of Evidence classify hearsay exceptions into two groups: those admissible only when the declarant is unavailable to testify, FED. R. EVID. 804, and those admissible regardless whether the declarant is available to testify, FED. R. EVID. 803. Based, at least in part, on Wigmore's faith in the reliability of excited utterances, the drafters of the Federal Rules of Evidence included it as one of the hearsay exceptions admissible even if the declarant is available to testify. In essence, "to accept Wigmore's position, one must be convinced that the declarant's excited statement is more trustworthy than her live recollection of the event at trial." Moorehead, supra note 21 , at 239 .

31. Research reveals that an inordinate number of early excited utterance cases involved railroads/trains and horse-drawn carriages/wagons. See Orenstein, supra note 15, at 197. Today, civil cases involving an excited utterance run the gamut, with the most frequent type being automobile accident cases. In criminal cases, the bulk of excited utterance incidents come in the form of a statement identifying the perpetrator. The author reached these conclusions after researching hundreds of cases on Westlaw. Prior to the modern era, to be admissible an excited utterance could not be in response to questioning; the statement had to originate solely from the declarant's reaction to the startling event: "Where no questions have been asked, the courts are willing to concede that physical shock to the declarant is likely to produce the truth if the utterance comes before time to misrepresent has been afforded him." Hutchins \& Slesinger, supra note 29, at 433-34. However, "[a]lthough dying in agony, if, in response to an inquiry as to the identity of his assailant, the declarant says that the defendant shot him, the statement must be excluded." Id. at 433 . Also, prior to the modern era, only declarants involved in the startling event were considered eligible for the excited utterance exception; statements made by a casual bystander (such as the unidentified bystander in our truck vs. minivan example) were not considered admissible as excited utterances because such statements were "by no means so reliable" as those made by persons actually subjected to harm or potential harm. Id. at 434 . In the modern era, however, excited utterances made in response to questioning - even police questioning - may be admissible under the exception. See, e.g., United States v. Martin, 59 F.3d 767, 770 (8th Cir. 1995) (simply because declarant's 
because although hearsay, the statement is admissible under the excited utterance exception to the rule against hearsay. ${ }^{33}$

The anonymous bystander's statement ascribing fault to the truck driver is presumed accurate based on "assumptions about certain human behaviors thought to connote truthfulness." 34 According to psychologists and behavioral experts, historically, a statement's reliability could be inferred from the statement's spontaneity, society believing that "[w]hen someone speaks impulsively and reflexively about an event that has just occurred, he or she is thought unlikely to have either the time or presence of mind to fabricate the information." 35 As long as the event was exciting enough to cause shock that in turn resulted in the declarant falling into an emotional state, a statement uttered while still under the stress of that emotion that is "so clearly connected (with the occasion) that the declaration may be said to be the spontaneous explanation of the real cause" 36 is admissible as an excited utterance. In general, "the theory is that the individual is so consumed by the stress of the startling occurrence that she is unable to act to promote her own self-interest."

"statements responded to a question does not render them inadmissible"); United States v. Lim, 984 F.2d 331, 336 (9th Cir. 1993) ("statements of Apostol immediately following his arrest were admissible as excited utterances under FED. R. EVID. 803(2)"). Also, statements made by casual bystanders may be admissible as excited utterances. FED. R. EVID. 803(2) advisory committee's note ("Participation by the declarant is not required: a nonparticipant may be moved to describe what he perceives, and one may be startled by an event in which he is not an actor."). The excited utterance exception clearly has broadened and expanded over time, something that perhaps would have made Wigmore grin.

32. All of the hearsay exceptions contained within FED. R. EVID. 803 apply regardless of the availability of the declarant to testify at trial. Therefore, even if the bystander is later identified and available to testify at trial regarding what she observed, her excited utterance is still admissible, even if the bystander takes the stand and recants. However, if the bystander never testifies, the jury has no opportunity to assess her demeanor, and the cross-examining attorney cannot question her regarding whether she witnessed the entire event, had been drinking alcohol or otherwise did anything to impair her perception, knows any of the parties or possesses a reason to be bias, was simply joking, has ever been convicted of a felony or a crime involving false statement, or any other question that probes the reliability of the declarant's statement alleging fault; thus are the dangers of admitting hearsay where the declarant never testifies - no cross-examination to ferret out credibility, accuracy, or truth.

33. FED. R. EVID. 803(2).

34. Lucy S. McGough, Hearing and Believing Hearsay, 5 Psychol. PuB. POL'Y \& L. 485, 486 (1999); see also Hutchins \& Slesinger, supra note 29, at 436 ("The desire to lie requires time and reflection to develop. And the intervention of reflection may be avoided by giving it no time to occur, thus rendering lying difficult, if not impossible.").

35. McGough, supra note 34, at 486.

36. Hutchins \& Slesinger, supra note 29, at 432 (quoting Leahy v. Cass Ave. \& Fair-Ground. Ry. Co., 10 S.W. 58, 60 (Mo. 1888)); see also 2 JACK B. Weinstein \& MARGARET A. BERGer, WeINSTEIN's FEDERAL EVIDENCE § 803(2)[05] (Joseph M. McLaughlin \& Mathew Bender eds., 1997) ("If the subject matter of the statement is such that it would likely be evoked by the event, the statement is typically admitted.").

37. Miller, supra note 18 , at 56-57. 
Professor Wigmore extolled the reliability of a statement uttered during or immediately after an exciting event because "in the stress of nervous excitement the reflective faculties may be stilled and the utterance may become the unreflecting and sincere expression of one's actual impressions and belief." 38 Such statements, Wigmore argued, are presumed credible because they represent "an immediate perception unhampered by the potential blurrings and fadings of memory," 39 "the contemporaneous nature of the remarks provides insufficient time for fabrication[, and] the declarant uttered hearsay while in the throes of excitement caused by having witnessed a startling event."40 Wigmore's criteria for the reliability, and thus admissibility, of such hearsay statements were, in substance, adopted by the Federal Rules of Evidence: Wigmore's (1) "exciting occasion" exclamation" 42 immediately after the occasion that, (3) relates to "the circumstances of the ... exciting occasion"43 became the Federal Rules of Evidence's "statement relating to a startling event or condition, made while the declarant was under the stress of excitement that it caused." 44

38. 6 WigmORE, supra note 23 , at $\S 1747$. Wigmore explained more fully that:

under certain external circumstances of physical shock, a stress of nervous excitement may be produced which stills the reflective faculties and removes their control, so that the utterance which then occurs is a spontaneous and sincere response to the actual sensations and perceptions already produced by the external shock. Since this utterance is made under the immediate and uncontrolled domination of the senses, and during the brief period when considerations of self-interest could not have been brought fully to bear by reasoned reflection, the utterance may be taken to be particularly trustworthy ....

Id. Wigmore excerpts a handful of early cases from both England and America wherein courts admitted into evidence "spontaneous exclamations" because they met certain reliability criteria or excluded them because they failed to do so; however, no case cited by Wigmore questions the legitimacy of the excited utterance exception. Id. The earliest champion of the spontaneous statement, Wigmore "isolated and promoted" the excited utterance as an admissible hearsay exception, and the exception's place in modern American jurisprudence is a direct result of Wigmore's efforts. Orenstein, supra note 15, at 169 (citing 4 JACK B. WEINSTEIN \& MARGARET A. BERGER, WEINSTEIN's EVIDENCE $§ 803(2)[01][D])$.

39. Stanley A. Goldman, Distorted Vision: Spontaneous Exclamations as a "Firmly Rooted" Exception to the Hearsay Rule, 23 LOY. L.A. L. REV. 453, 458 (1990) (citing 6 WIGMORE, supra note 23 , at $\S \S 1705(\mathrm{~b}))$.

40. Id. (citing Foster, supra note 27, at 317-18; BROUN ET AL., supra note 16, at $\S 297 ; 6$ WIGMORE, supra note 23 , at $\S \S 1747,1949)$.

41. 6 WIGMORE, supra note 23 , at $\S 1746$.

42. Id.

43. Id.

44. FED. R. EvID. 803(2). The Supreme Court of the United States formally accepted the excited utterance as a hearsay exception in White v. Illinois. 502 U.S. 346, 352-57 (1992). Most state evidentiary codes employ identical — or substantially similar-language to that of FED. R. EVID. 803(2) when defining an admissible excited utterance. Id. at 355 n.8. 
Prior to the enactment of the Federal Rules of Evidence, both federal and state case law generally held that an excited utterance may be admissible as an exception to the rule against hearsay. ${ }^{45}$ Wigmore and other early commentators cite hundreds of cases from the 1700 s through the early 1900 s wherein courts ruled hearsay statements admissible based on their spontaneity after an exciting event and often lauded the quality and reliability of such statements. ${ }^{46}$ Subsequent to the enactment of the Federal Rules of Evidence, many states adopted evidence codes substantially similar to the Federal Rules, ${ }^{47}$ while other states simply rely on established case law in ruling admissible an excited utterance. ${ }^{48}$ As of 2014 , more than four-fifths of all the states, to varying degrees, recognize the excited utterance as an admissible hearsay exception under certain circumstances. $^{49}$

Supporters of the excited utterance exception ${ }^{50}$ believe the anonymous bystander's statement is cloaked in reliability ${ }^{51}$ because the

45. See, e.g., 6 WIGMORE, supra note 23 , at $§ 1747$.

46. E.g., id. Wigmore discussed an 1834 manslaughter case wherein a horse-drawn cabriolet ran over a pedestrian and the pedestrian then uttered to a bystander-who testified at trial to the pedestrian's statement- that the driver of the cabriolet caused the injury: "It was the best possible testimony that under the circumstances can be adduced to show what it was that had knocked the deceased down." Id. (quoting Rex v. Foster, (1834) 172 Eng. Rep. 1261 (K.B.)). Wigmore also discussed a railroad accident case, explaining: "The statement of Leverett was made immediately after he was run over.... It was an emanation of the act in question and so connected with the cause of his injuries as to preclude any idea that it was the product of calculated policy." Id. (quoting Little Rock R.R. Co. v. Leverett, 3 S.W. 50, 53 (Ark. 1886)).

47 See, e.g., Charles W. Ehrhardt, EhrhardT's Florida Evidence $§ 102.1$ (2014 ed.), available at Westlaw (last updated June 2014) (Florida's "Evidence Code is patterned after the Federal Rules of Evidence. Many of its provisions are identical to the Federal Rules").

48. See, e.g., Brief for the State of California et al. as Amici Curiae Supporting Respondent at 15-16, White v. Illinois, 502 U.S. 346 (1992) (No. 90-6113) (listing state statutes).

49. White, 502 U.S. at 355 n. 8 (asserting that as of 1992, four-fifths of all states recognize the excited utterance exception). The author's research reveals that this remains true as of 2014.

50. See, e.g., Mason Ladd, The Hearsay We Admit, 5 OKLA. L. REv. 271, 280 (1952) (noting that statements uttered under the influence of the stress of an exciting event create an inference the declarant is speaking sincerely); McFarland, supra note 21, at 916; Roger C. Park, Visions of Applying the Scientific Method to the Hearsay Rule, 2003 MicH. ST. L. REV. 1149, 1151 (2003) ("excited utterances... are likely to be more accurate than many other types of hearsay."). McFarland provides that:

The witness perceives an event; the witness blurts out a statement concerning the event. Conceivably, a clever prevaricator can have a previously prepared cadre of falsehoods to utter while an event is taking place, but that possibility is small to the point of nonexistence. A witness suddenly or unexpectedly confronted with an event is almost certain to blurt out a truthful [statement] about that event. 
bystander had no time to fabricate, no reason to fabricate, and no time to reflect and analyze what just happened such that the bystander then utters a mere impression, summary, or conclusion of his belief about what happened rather than just blurting out exactly what he saw. ${ }^{52}$ Put simply, supporters believe exciting circumstances result in the truth being uttered when the statement occurs soon after an exciting event. ${ }^{53}$ Critics of the excited utterance exception argue, ${ }^{54}$ based on psychological and empirical evidence ${ }^{55}$-as well as on good old-fashioned common sense ${ }^{56}$ - that evidence law should be "awakened from its dogmatic slumber" $" 57$ and an alternative analysis should be crafted to determine whether hearsay statements such as those made by the anonymous bystander are sufficiently reliable to admit into evidence and be relied upon by the jury.

\section{APPLICATION OF THE EXCITED UTTERANCE EXCEPTION}

From the $1700 \mathrm{~s}$ to the $1970 \mathrm{~s}$, the excited utterance exception appears, for the most part, to have functioned as designed: admitting certain hearsay statements containing at least some indicia of reliability that might assist jurors in appropriately deciding a case. ${ }^{58}$ Whether

51. The Supreme Court ruled that an excited utterance may be admitted into evidence when it "is so trustworthy that adversarial testing can be expected to add little to its reliability." White, 502 U.S. at 357.

52. McCormick wrote that, "the ultimate question is whether the statement was the result of reflective thought or whether it was rather a spontaneous reaction to the exciting event." KENNETH S. BROUN ET AL., MCCORMICK ON EVIDENCE $§ 272$ (John William Strong ed., 4th ed. 1992).

53. The Latin phrase in vino veritas - in wine there is the truth - is another example of similar folk wisdom asserting that, under certain circumstances, people simply do not lie. In Vino Veritas, MERRIAM-WEBSTER, http://www.merriam-webster.com/dictionary/in\%20vino\%20veritas (last visited Apr. 7, 2015). Analogizing the number of inaccuracies, misstatements, and blatant lies told when a declarant is under the influence of alcohol to statements made under excited utterance conditions may lead one to conclude that excited utterances are not as reliable as Wigmore argued.

54. See, e.g., Angela Conti \& Brian Gitnik, Federal Rule of Evidence 803(2): Problems with the Excited Utterance Exception to the Rule on Hearsay, 14 ST. JOHN'S J. LEGAL COMMENT. 227, 228 (1999) (citing Orenstein, supra note 15, at 161; Moorehead, supra note 21, at 203) ("[C]ritics take every opportunity to attempt to limit its application or abolish the rule completely.").

55. See infra Part III.B.2 (discussing the psychological aspects of excited utterances).

56. In his concurring opinion in United States v. Boyce, Judge Posner quoted Hutchins and Slesinger: "One need not be a psychologist to distrust an observation made under emotional stress; everybody accepts such statements with mental reservation.” 742 F.3d 792, 801 (7th Cir. 2014) (Posner, J., concurring) (quoting Hutchins \& Slesinger, supra note 29, at 437), cert. denied, 134 S. Ct. 2321 (2014).

57. Id. (Posner, J., concurring).

58. Perhaps it's simply a belief that, in the past, people were not as devious and calculating as they appear to be today-whether a child threatens his parent that he will call the Department of Children and Family Services to claim abuse if he does not get his way, or one spouse murders the other spouse in an elaborate plot premised on the surviving spouse's ability to lie effectively to the 
employing the exact language of the Federal Rules of Evidence or the substantially similar language of most states' evidence codes, in general the excited utterance exception requires three things: (1) a startling event causing stress; (2) a statement made while the declarant is still under that stress; and, (3) that the statement relate to the startling event. ${ }^{59}$ As simple as those three requirements may seem, different jurisdictions interpret the requirements in disparate manners, leading to divergent judicial opinions whether a particular statement is admissible. ${ }^{60}$ Since

police while making exculpatory excited utterances - but a review of hundreds of cases from the 1700 s to the 1960 s reveals that courts simply trusted alleged excited utterances more so in the past than today, not because rules, codes, or case law mandated such, but based on the perceived reliability of such type statements. See, e.g., Pfeifers of Ark. v. Rorex, 286 S.W.2d 1, 4 (Ark. 1956) (in negligence case against department store for fall suffered by patron allegedly due to slippery floor, statement immediately after incident that the floor should have been cleaned admitted as a spontaneous declaration); State v. Gilbreath, 267 S.W. 880, 882 (Mo. 1924) (statement to her mother by teen that her 23-year-old cousin attempted to rape her uttered within minutes of incident admissible as a spontaneous declaration). However, courts one hundred years ago were not naïve; just as today, past courts were wary of self-serving statements disguised as excited utterances. See, e.g., Hedlund v. Minneapolis State Ry. Co., 139 N.W. 603, 605 (Minn. 1913) (in trolley car accident, statement by trolley car motorman that automobile driver was at fault admitted as a spontaneous declaration because it most likely was a fabrication). The court in Hedlund explained that the spontaneous declaration:

had a tendency to show that the motorman was not only excited, but immediately charged plaintiff with running into the [trolley] car, a charge that no evidence supported. It served to indicate a desire to throw the entire blame for the accident upon plaintiff, and to clear the motorman. Not unlike evidence that a person accused of [a] crime has attempted to accuse others of its commission, the statement has a bearing and is relevant on the question of the speaker's guilt. In addition to this, the violent and unjustifiably profane and indecent nature of the remark tended to show that the motorman was not in the calm state of mind that his testimony was apparently intended to show he was in when he discovered the emergency that existed.

Id. at 605. In essence, the Minnesota Supreme Court appears to have admitted the motorman's statement as an excited utterance when today it most likely would be considered an admission/opposing party's statement. Id.; see also FED. R. EVID. 801(2). In modern times, so powerful and/or damning is an admission that the Federal Rules of Evidence do not even consider an admission as hearsay, instead allowing that - even though by definition it should be considered hearsay - it nonetheless does not qualify as such under the Rules and therefore is admissible without the need to locate an exception under which to admit it. FED. R. EVID. 801(d)(2). Consider how compelling, then, the excited utterance was to courts a hundred years or more ago: rather than allowing into evidence an opposing party's statement as an admission, the court instead admitted it as an excited utterance.

59. See, e.g., FED. R. EVID. 803(2) ("A statement relating to a startling event or condition, made while the declarant was under the stress of the excitement that it caused.").

60. For example, some federal circuits employ different approaches. See Matthew D. Janssen, The Butler Did It!!!: A Critical Analysis of the Excited Utterance Exception to the Hearsay Rule as Applied in the Third Circuit, 47 VILL. L. REV. 1117, 1124-29 (2002) (discussing different tests for analyzing alleged excited utterances). Janseen explains that the First, Seventh, and Tenth Circuits employ a "three element" approach (i.e., (1) did a startling even occur; (2) was a statement made while under stress caused by the event; (3) does the statement relate to the event), the Eighth Circuit 
the 1980s, however, a steady drumbeat has sounded, building on earlier, if sporadic, criticism of the excited utterance ${ }^{61}$ and repeating calls to reexamine the exception with any eye toward revising it - or scrapping it altogether. $^{62}$

\section{A. Why the Excited Utterance Exception Works, Sometimes}

At first glance, the excited utterance exception makes perfect sense. The author was recently driving to the law school to teach Evidence and narrowly avoided hitting a motorcycle and SUV involved in a fatal intersection crash. Moments later, standing on the side of the road as emergency personnel loaded injured persons into ambulances, the author made a statement to the police and could not have lied even had the author desired to do so. The shock of nearly becoming part of an accident involving a fatality-coupled with observing emergency medical technicians administering aid to the injured driver and passenger - certainly results in many declarants' inability to fabricate. ${ }^{63}$ To most people, the credibility of the author's excited utterance to the police regarding the cause of the crash might be considered unassailable.

Over the centuries that the excited utterance exception has been in existence, thousands of cases have been decided involving the

\footnotetext{
uses a "multi-factor" test exploring six relevant factors (i.e., (1) the time lapse between event and statement; (2) whether the statement is in response to an inquiry; (3) declarant's age; (4) declarant's mental and physical condition; (5) characteristics of the event; (6) statement's subject matter), the Fourth Circuit has a "two element" approach (i.e., (1) declarant must experience a startling event; (2) declarant reacts from stress caused by the event and not from reflective thought), and the Sixth Circuit employs a different "three element" test than the First, Seventh, and Tenth Circuit's (i.e., (1) a startling event; (2) declarant makes statement before time to fabricate; (3) statement made under stress caused by event). Id. Similarly, the author's research revealed that states approach their excited utterance exceptions in a varied manner.

61. See, e.g., Hutchins \& Slesinger, supra note 29, at 440 ("Thus it appears that the spontaneous declarations regarded with least favor by the courts are more trustworthy than those which most of them admit without question: those where the trial judge rules that the statement was made under the influence of severe physical shock"). Hutchins and Slesinger assert: "The rule might very well read: [h] earsay is inadmissible, especially ... if it be a spontaneous exclamation." Id. at 439.

62. See, e.g., Goldman, supra note 39, at 456, 463 (citing Dutton v. Evans, 400 U.S. 74, 88-89 (1970)) (stating that "many spontaneous exclamations are not made under sufficiently reliable circumstances [and] therefore they should not be classified as a firmly rooted hearsay exception" and that "the spontaneous exclamation exception fails to comply with the trustworthiness factors"); Moorehead, supra note 21, at 203 (arguing that the res gestae exceptions-including the excited utterance - "should be abolished" because they are not sufficiently reliable).

63. The accuracy of excited utterances - considering the stress the declarant is required to be
} under for the exception to apply—is an entirely separate concern. See infra Part III.B.2. 
exception. $^{64}$ It is not difficult to locate cases where the exception appears
to have been applied appropriately to admit a credible excited utterance ${ }^{65}$
or to appropriately deny admission of an alleged excited utterance. ${ }^{66}$

64. The advisory committee notes regarding FED. R. EVID. 803(2) note that the excited utterance exception "finds support in cases without number." FED. R. EvID. 803 advisory committee's note.

65. A relatively recent example from a federal appellate court is most illustrative of this point. In United States v. Robinson, according to excited utterances by the defendant's wife made at the scene to police officers, defendant Robinson rammed his wife's vehicle with his own, fired two shots into his wife's vehicle, and then threatened to kill his wife if she informed the police. $430 \mathrm{~F}$. App'x 761, 763 (11th Cir. 2011). Three witnesses (Robinson's mistress, her mother, and her nephew) alleged that they were in the vehicle with Robinson, that none of what the wife told police was accurate, and that Robinson committed no crimes. Id. at 764. Robinson was later arrested but the wife recanted her previous statements to police, refused to testify, and avoided trial subpoena. Id. at 763, 765. After hearing evidence that domestic violence victims often recant their allegations subsequent to later contact with their alleged abusers, the district court admitted the wife's statements to police as excited utterances. Id. at 765-66. The Eleventh Circuit affirmed, reasoning that because the other witnesses had all committed perjury (their testimony did not correspond to the evidence), the district court correctly credited the officers' testimony regarding the wife's excited utterances. Id. at 767. The court wrote:

[The wife's] original statements to law enforcement were reliable, while her later recantation was likely the product of duress and fear.... [T] he district court correctly observed that [the wife's] hearsay statements were admissible as excited utterances under Federal Rule of Evidence 803(2). [The wife] made the statements to the officers immediately after, and while still under the stress of, the startling confrontation with Defendant Robinson.

Id. (internal citations omitted). Based on physical evidence corroborating the excited utterances (i.e., a smashed bumper and paint chips from Robinson's vehicle found at the scene, along with the bullet holes in the wife's vehicle), it appears the district court correctly concluded that the excited utterances were accurate and the other witnesses' testimony inaccurate/fabricated. Id. Without admission of the wife's excited utterances, however, the charges against Robinson could not have been proven based on the physical evidence alone. Id. at 766-67. This case appears to be one where excited utterances were necessary to produce the "correct" outcome, and without admission of the excited utterances the correct outcome would not have been achieved. Id. at 767 . In the civil context, Swift Transportation v. Angulo, is illustrative. 716 F.3d 1127 (8th Cir. 2013). Plaintiff Turner sued Defendant Swift subsequent to a vehicle accident, alleging that a truck owned and operated by Swift forced him off the road into a ditch. $I d$. at 1130. Minutes after the accident, while lying injured in a ditch and awaiting arrival of emergency personnel, Turner told a bystander that a "Swift truck" forced him off the road. Id. at 1130-31. While still disoriented one hour later at the hospital, Turner repeated his allegation to medical personnel. Id. at 1131. Several hours later, while lying in a hospital bed in pain, Turner again repeated his allegation. Id. Prior to trial, Turner lost most of his memory regarding the accident due to traumatic brain injury and thus was unable, at trial, to identify the truck that forced him off the road. Id. at 1132. The district court nonetheless admitted as excited utterances Turner's hearsay statements to the bystander and medical personnel ascribing fault to Swift, and the Eighth Circuit affirmed. Id. at 1136-37. Without admission of Turner's excited utterances, almost no other evidence that Swift operated the negligent truck existed. $I d$. at 1136-38. Therefore, it appears the excited utterance, in this case, operated to hold a negligent party liable and, without the admission of Turner's hearsay statements, the outcome likely would have been different.

66. In Gonzalez v. City of New York, the plaintiff in a slip and fall case alleged that immediately after the "accident, a security guard saw her on the floor, and exclaimed 'oh my God, 
Thus, courts' reliance on historical precedent may be well founded. The majority in Boyce stressed that the excited utterance exception is wellestablished and that the defendant Boyce did "not ask us to find the exception[] utterly invalid." ${ }^{, 7}$ Legal opinions in which the excited utterance plays a role frequently recite that the exception is "firmly established" or "deeply rooted," 68 rarely questioning the exception in the manner that both the majority and concurrence do in Boyce.

Whether the declarant testifies at trial —or is actually identified at all - contributes to courts' analyses of the admissibility of an excited utterance $^{69}$ Although "[t]he availability or unavailability of a declarant as a witness does not affect the applicability of the exception," advisory committee notes accompanying Federal Rule of Evidence 803(2) caution that "when [a] declarant is an unidentified bystander, the cases indicate hesitancy in upholding the statement alone as sufficient."71

someone else fell."” 109 A.D.3d 510, 511 (N.Y. App. Div. 2013). The trial court admitted the security guard's statement as an excited utterance, and the jury found for the plaintiff. Id. The appellate court reversed, ruling that admission of the statement as an excited utterance was error: "the plaintiff was required to demonstrate that 'at the time of the statement the declarant was under the stress of excitement caused by an external event sufficient to still [his] [sic] reflective faculties and had no opportunity for deliberation.' Here, the plaintiff failed to meet that burden." Id. at 512 (quoting Tyrrell v. Wal-Mart Stores, 762 N.E.2d 921, 922 (N.Y. 2001)) (citing Laguesse v. Storytown U.S.A., 745 N.Y.S.2d 323, 325-26 (N.Y. App. Div. 2002); Berzon v. D’Agostino Supermarkets, Inc., 792 N.Y.S.2d 94, 95 (N.Y. App. Div. 2005); Rodney v. Brookhaven, 644 N.Y.S.2d 321, 322 (N.Y. App. Div. 1996)).

67. United States v. Boyce, 742 F.3d 792, 796-97 (7th Cir. 2014) (Posner, J., concurring), cert. denied, 134 S. Ct. 2321 (2014). From this language, one might infer that the majority perhaps may have considered the Defendant's motion to rule the excited utterance no longer a valid exception to the rule against hearsay, had the Defendant made such a motion.

68. Chief Justice Rehnquist's opinion in White v. Illinois makes clear that the United States Supreme Court considers the excited utterance exception "firmly rooted" because it carries "sufficient indicia of reliability to satisfy the reliability requirement posed by the Confrontation Clause." 502 U.S. 346, 345 n.8 (1992) (citing Idaho v. Wright, 497 U.S. 805, 817, 820-21 (1990); Bourgaily v. United States, 483 U.S. 171, 182-84 (1987)). Rehnquist goes on to note that the excited utterance "is at least two centuries old and may date to the late seventeenth century." Id. (internal citations omitted). Thus the Supreme Court, as most other courts, appears simply to believe that courts have always done it this way-most likely for a good reason-so we're just going to keep doing it this way. That rationalization is exactly what Judge Posner criticizes in his Boyce concurrence: "the exception for excited utterances rests on no firmer ground than judicial habit, in turn reflecting judicial incuriosity and reluctance to reconsider ancient dogmas." Boyce, 742 F.3d at 802 (Posner, J., concurring).

69. E.g., Miller v. Keating, 754 F.2d 507, 510 (3d Cir. 1985) (reversing district court's admission of alleged excited utterances made by unidentified declarant, reasoning that "the unidentifiability of the declarant is germane to the admissibility determination").

70. Bornstad ex rel. Estate of Bornstad v. Honey Brook Twp., No. C.A.03-CV-3822, 2005 WL 2212359, at*7 (E.D. Pa. Sept. 9, 2005) (citing United States v. Brown, 254 F.3d 454, 458 (3d Cir. 2001)), aff'd, 211 F. App'x 118 (3d Cir. 2007).

71. FED. R. EvID. 803 advisory committee's note; see also Brown, 254 F.3d at 461 . The court in Brown wrote that: 
In general, therefore, courts scrutinize more closely an alleged excited utterance made by an unidentified declarant, but such statements are not "ipso facto inadmissible under FED. R. EVID. 803(2)."72

In some cases, the excited utterance may accompany its sister exception - the present sense impression ${ }^{73}$ - as occurs in Boyce. But, whereas the present sense impression requires that the statement come during or immediately after the event and that it be one "describing or explaining" the event, the excited utterance is a much broader exception, allowing statements that are merely "relating" to the event that may be uttered immediately after-or even weeks after- the event. ${ }^{74}$ Neither

Brown also argues that in admitting the two [unidentified] men's statements, the District Court ran afoul of our holding in Miller. We do not agree. Although we did state in Miller that a party seeking to introduce a statement by an unidentified declarant under Rule 803(2) "carries a burden heavier than where the declarant is identified to demonstrate the statement's circumstantial trustworthiness," we also emphasized that "such statements are admissible if they otherwise meet the criteria of[Rule] [sic] 803(2)." For the reasons set forth supra, Officer Hughes's testimony satisfies all the criteria of that rule .... [T] he declarants did in fact claim to have personally seen the startling event: a man wielding a gun. Moreover, the declarants are simply stating what they observed. They are not giving an opinion, which is what occurs when a declarant points a finger of fault for causing an accident.... Furthermore, even if we did interpret the "heavier burden" for unidentified declarants, established in Miller, to require corroboration of the startling event beyond the excited utterance itself, the fact that Officer Hughes almost immediately came upon Brown, who was visibly carrying a gun and who was identified as the gun brandisher by the two declarants, provides such corroboration.

Id. (quoting Miller, 754 F.2d at 510) (citing United States v. Collins, 60 F.3d 4, 8 (1st Cir. 1995)).

72. Miller, 754 F.2d at 510.

73. See FED. R. EvID. 803(1). Admissibility under the present sense impression exception, however, is more rare than under the excited utterance exception, and cases involving it "are far less numerous." FED. R. EvID. 803 advisory committee's note; see also supra note 4 (discussing the contrast between the number of cases involving each exception). Commentators have noted that "[u]ntil the adoption of the Federal Rules of Evidence, only a few jurisdictions recognized the present sense impression exception." Imwinkelried, supra note 23, at 327 (citing 2 GEORGE E. DIX ET AL., MCCORMICK ON EVIDENCE § 271 (Kenneth S. Broun ed., 6th ed. 2006)).

74. FED. R. EvID. 803(1), (2). As discussed earlier, the excited utterance exception may allow for admission of statements made hours - or even days - after the event; the present sense impression is limited to concurrent statements or those made within a few moments of the event. See supra note 26 . Considering the advent and availability of the cellular/smart phone over the past decade, the present sense impression may be aptly demonstrated by the following scenario: a woman walking down a dark alley while talking on her cell phone to her sister as she narrates: "There is a tall, bald man wearing a leather coat following me. He has a dragon tattoo on his cheek and six hoop earrings in his left earlobe. Now he's chasing me!" The phone goes dead. At the murder trial of the tall, bald, dragon-tattooed defendant with six hoop earrings, the sister testifies to the victim's description of the man and events under the present sense impression exception. Juxtapose that scenario with the victim surviving the attack and minutes later calling her sister back and exclaiming into the phone: "Send the police and an ambulance here now! A tall, bald man with a dragon tattoo on his cheek and six hoop earrings just attacked me and I need help now!" Under this alternative scenario, the declarant's statements most likely would be admitted at trial pursuant to the excited utterance exception. 
exception requires corroboration, ${ }^{75}$ but only the excited utterance may come in response to questioning. ${ }^{76}$ Courts continue to favor the excited utterance over the present sense impression, ${ }^{77}$ if only out of judicial habit, but greater numbers of legal commentators are now attacking both exceptions, with increased criticism of the excited utterance due to its inherent flaws caused by psychological concerns. ${ }^{78}$

\section{B. But Does the Excited Utterance Exception Really Work?}

Despite the excited utterance's potential attributes and its past contributions to the jury's function of divining the truth to render a just verdict, two severe concerns underlie the exception: (1) the fabricating declarant; and, (2) the impaired or inaccurate declarant. Some commentators favor admitting all hearsay and then simply allowing the

75. Pursuant to the language of each rule, neither FED. R. EvID. 803(1) nor 803(2) requires corroboration for the exception to apply; however, with the present sense impression, corroboration was assumed - at least prior to the enactment of the Federal Rules—-because:

the statement is contemporaneous with the event, it is made at the place of the event. Consequently the event is open to perception by the senses of the persons to whom the declaration is made and by whom it is usually reported on the witness stand. The witness is subject to cross-examination concerning the event as well as the fact and content of the utterance, so that the extra-judicial does not depend solely upon the credit of the declarant.

Morgan, supra note 16, at 236. However, subsequent to the enactment of the Federal Rules of Evidence, although "courts sometimes focus on the corroboration or the lack thereof in admitting or excluding present sense impressions, [] the truth is that the rule does not condition admissibility on the availability of corroboration." United States v. Ruiz, 249 F.3d 643, 647 (7th Cir. 2001) (internal citations omitted). For the proposition that excited utterances require no corroboration, see United States v. Boyce, 742 F.3d 792, 799 (7th Cir. 2014) (Posner, J., concurring), cert. denied, 134 S. Ct. 2321 (2014) ("corroboration is not required for admissibility"); State v. Cox, No. 99 BA 46, 2001 WL 301429, at *2 n.2 (Ohio Ct. App. Mar. 20, 2001) ("The admission of an excited utterance does not require corroboration or independent proof ....").

76. See United States v. Frost, 684 F.3d 963, 974 (10th Cir. 2012) (regarding declarant's excited utterances in response to a police officer's inquiry: "even if prompted by questioning, a statement may be admissible if the questions are somewhat open-ended" (citing United States v. Phelps, 168 F.3d 1048, 1055 (8th Cir. 1999) (affirming admission of excited utterances in response to police officer's questioning that was not "suggestive"))); United States v. Iron Shell, 633 F.2d 77, 81, 86 (8th Cir. 1980) (statements in response to police officer's question "what happened?" admitted as excited utterances); see also United States v. Jennings, 496 F.3d 344, 347, 350 (4th Cir. 2007) (victim's statements in response to bystander's question "what's wrong?" admitted as excited utterances).

77. Some commentators have written that the present sense impression "has not proved as useful as anticipated." Christopher B. Mueller \& LAIRD C. KiRKPATRICK, Federal EVIDENCE $\S$ 8:67 (3d ed. 2007), available at Westlaw (last updated May 2014).

78. See infra Part III.B.2. 
jury to assess the statement's reliability; ${ }^{79}$ however, the adage "you can't un-ring a bell" may persuade others that the trial judge should maintain the gatekeeper function of admitting only relevant, at least somewhat reliable, evidence, while the jury fulfills its duty to examine that evidence uninfluenced by having heard a statement that never should have been admitted because it simply had no indicia of reliabilitybecause, if the jury hears it, the jury will consider the statement, either consciously or subconsciously, in its deliberations, regardless whether the judge issues a curative instruction. ${ }^{80}$ The excited utterance exception, however, may allow into evidence statements that are flat-out lies, or statements that are no more reliable than ones mumbled during a night's sleep.

\section{Fabrication}

In People v. Simpson, the complainant alleged that Simpson threatened her with a box-cutter, pushed her into an alley, robbed her, and then sexually assaulted her. ${ }^{81}$ The complainant further alleged that Simpson then tried to force the complainant up to her apartment-to steal more from her and perhaps sexually assault her again - but with the help of two friends passing by, the complainant escaped from Simpson and then momentarily assisted her friends in chasing Simpson. ${ }^{82}$ Five minutes after the incident-while her friends were still chasing Simpson-the complainant called the police from her apartment and reported (on a recorded 911 call) that her attacker had a gun and a knife, even though Simpson never possessed a gun. ${ }^{83}$ At Simpson's trial, the complainant testified that she consciously lied about the defendant possessing a gun because, "I knew that if I said there was a gun, that the

79. See, e.g., Michael L. Siegel, Rationalizing Hearsay: A Proposal for a Best Evidence Hearsay Rule, 72 B.U. L. REV. 893, 915 (1992) ("Twelve jurors are at least as capable of weighing hearsay as a single judge."); Tribe, supra note 14, at 957 (the English system has "seen fit to virtually abandon the hearsay rule in civil cases" (citing the Civil Evidence Act, 1968, c. 64, pt. 1, § 2(1) (U.K.))).

80. Situations involving a curative instruction so frustrated the author when trying cases. No matter how the judge phrased the curative instruction, the belief persisted that jurors perked up their ears and reviewed in their minds even more diligently the statement the judge told them to disregard: It was as if the jury members thought to themselves, "if the judge told me to ignore, it must have been important, or at least juicy." It is like putting a box on a high shelf and telling a child he is not to look in the box; the first thing the child does when the parent turns her back is start climbing the shelves. Curative instructions are certainly necessary, but the legal system should do it all it can to limit the instances in which they are employed.

81. 656 N.Y.S.2d 765, 766 (N.Y. App. Div. 1997).

82. Id.

83. Id. at 767 . 
cops would come quicker." 84 Over Simpson's objection, the trial court admitted the complainant's hearsay statements on the 911 recording as excited utterances. ${ }^{85}$ Simpson was convicted, and he filed an appeal. ${ }^{86}$ The appellate court affirmed the conviction and the trial court's admission of the complainant's recorded 911 statements because the excited nature of the statements subsequent to such a horrifying event "overcomes the significance of her admitted lie to the police about the gun." "87

Many argue that admission of statements such as those made by the complainant in Simpson is exactly what is wrong with the excited utterance exception: even though circumstances appear to demonstrate the declarant still remains under the stress of an exciting event-who would ever dispute that, five minutes after someone is robbed and raped at knife-point and is about to be robbed and perhaps raped again, she is still under the stress of the incident - the declarant clearly had the mental and reflective acumen to fabricate a lie designed to accomplish the arrest of her assailant. In Simpson, the dissenting justice reasoned that, "the complainant had the cognitive ability to purposely lie to the 911 operator that the defendant possessed a gun in an effort to prompt a more immediate police response demonstrates that she was acting 'under the impetus of studied reflection," and obviously she was not still under the stress of the event such that she did not have time to reflect or fabricate because she did indeed fabricate and with calculated reason to do so. ${ }^{88}$

84. Id.

85. $I d$.

86. Id.

87. Id. The appellate court noted that "the complainant's presence on the witness stand provided an additional justification for admission... since the defendant had the opportunity to verify and test the trustworthiness of her statements by cross-examination." Id. at 767-68 (citing People v. Buie, 658 N.E.2d 192, 198-99 (N.Y. 1995)). Similar to Simpson, in State v. Magers, the Washington Supreme Court affirmed admission of an excited utterance even though the declarant lied to police in a portion of the statement. 189 P.3d 126, 134 (Wash. 2008) ("We agree with the Court of Appeals that the fact that [the declarant] told the police a falsehood when she denied [the Defendant's] presence in her house does not mean that the remainder of her statements were not spontaneous and truthful.").

88. Simpson, 656 N.Y.S.2d at 768 (Joy, J., dissenting) (quoting People v. Edwards, 392 N.E.2d 1229, 1231 (N.Y. 1979)). Employing the majority's reasoning in Simpson, a Washington appellate court affirmed admission of a victim's inculpatory statements to police in a domestic violence case despite the victim's fabrication that the defendant's appearance at victim's home surprised her. State v. Al-Derawi, No. 61115-1-I, 2009 WL 1410714, at*1 (Wash. Ct. App. May 18, 2009). Telephone records confirmed that the victim had in fact called the defendant that day and was aware he was coming to the home. Id. at *4. The court reasoned that, since the police officer's testimony regarding the victim's statements did not specifically recount the victim's lie, there was no fabricated testimony heard by the jury. Id. at *5. This reasoning appears flawed: even though the victim lied to police, her inculpatory hearsay statements were admissible as excited utterances 
Based on the complainant's friends' testimony and the presence of the complainant's jewelry and a box-cutter in Simpson's possession, ${ }^{89}$ it appears that the complainant was telling the truth about the entire incident; however, one can easily envision a scenario where a wily declarant could employ the excited utterance as a means to perpetrate a fraud on the court in an effort to manipulate an unjust outcome or escape prosecution. $^{90}$

Dating back to its earliest beginnings, "the Anglo-American law of Evidence has been obsessed with the prevention of perjury" and this concern "had a major influence on the formulation of the hearsay rule." However, English courts believed that certain hearsay exceptions "did not pose significant risks of perjury" and therefore unanimously accepted the excited utterance as a valid exception because the surrounding circumstances were thought to indicate the declarant was "speaking sincerely." 92 Nothing about these early cases and early judicial

because the jury never heard the victim's lie. See id. Whether the jury heard the lie isn't the point. The excited utterance exception is only valid if the statement is reliable because it fits within the requirements of the exception. If the declarant fabricated any part of the statement, by definition aren't the requirements of the exception not met?

89. Simpson, 656 N.Y.S.2d at 766.

90. For anyone who has seen the Julia Roberts film Sleeping with the Enemy, the final scene may come to mind, wherein Laura holds a gun on her abusive husband while she dials 911. SLEEPING WITH THE ENEMY (Twentieth Century Fox 1991). The husband taunts her, threatening that he'll never let her go and that if he can't have her no one will. Id. Laura gasps into the phone what could only later be described as an excited utterance: "Come quickly! I've just killed an intruder!" Id. Then, Laura calmly and deliberately fires three shots, murdering her abusive husband. Id.

91. Imwinkelried, supra note 23, at 319, 321 (citing Edward J. Imwinkelried, The Worst Evidence Principle: The Best Hypothesis as to the Logical Structure of Evidence Law, 46 U. MIAMI L. REV. 1069 (1992)). Imwinkelried comprehensively traced the English courts' early efforts to root out perjury and analyzed why there was so much concern-i.e., an incentive for criminals to commit perjury under the Crown Witness system, a bounty paid by the government for successful prosecution of thieves, and such severe and abundant fraud in the civil realm that Parliament enacted the first Statute of Frauds. Id. at 320-21. Imwinkelried notes that "at early common law interested persons were incompetent as witnesses" because they had a reason/motive to fabricate. Id. at 321 . Ultimately, Imwinkelried concluded that the English "concern about perjury had a profound influence in shaping the common law of Evidence." Id.; see also McFarland, supra note 21, at 916 (that a declarant might have lied "is probably the danger of most concern for any hearsay statement").

92. Id.; see also 2 DIX ET AL., supra note 73, at $\S 272$. However, the original excited utterance exception admitted only spontaneous statements that were not in response to questioning because, "[a]s a result of interpolation of the question, what would otherwise be admissible becomes "not the natural and spontaneous outgrowth of [the event], but a mere narrative of a past transaction, and hence not a part of the res gestae." Hutchins \& Slesinger, supra note 29, at 433 (quoting People v. Westcott, 260 P. 901, 905 (Cal. Dist. Ct. App. 1927)); see also supra note 31. To this day courts fear fabrication: the majority in United States $v$. Boyce notes that "answering questions rather than giving a spontaneous narration could increase the chances that the statements were made with calculated narration, and, as we discussed, [the declarant] ran to another residence between the 
formulations centered on accuracy; it was all about perjury, and the stress of an exciting event was thought to defeat the ability to lie. ${ }^{93}$

Although empirical studies conclude that the risk of fabrication decreases "where only a matter of seconds or fractions of seconds separate a particular event and an individual's description of that event," 94 even early experiments reveal that, for some declarants, it takes less than one second to fabricate a lie. ${ }^{95}$ Modern studies confirm these early results and further show that "the truth took longer to [utter] than a previously conceived lie, and that even a lie fabricated on the spur of the moment required less than three seconds to create and utter." ${ }^{.96}$ As Judge Posner notes in his Boyce concurrence, "[m]ost lies in fact are spontaneous," 97 leading to the conclusion that some lies may attend the aftermath of an exciting event in the form of an excited utterance. Many parents know the experience of dashing into the kitchen after hearing the crash of broken plates only to ask the question "What happened?" and hear one's four-year-old exclaim in response, "It wasn't me; it was my brother!" 98 Some may argue that it is simply a natural human reaction to blame another for an exciting event rather than accept fault for the event oneself; such a fabricated assignment of blame often may take the form of an excited utterance.

Unique to the excited utterance exception is that no independent corroboration need exist to prove that a startling event occurred: the excited utterance itself may be employed as the sole proof that a startling event even happened. ${ }^{99}$ Therefore, unlike other hearsay exceptions, the

battery and her 911 call.” 742 F.3d 792, 797-98 (7th Cir. 2014), cert. denied, 134 S. Ct. 2321 (2014).

93. See Hutchins \& Slesinger, supra note 29, at 437 ("In order more fully to guard against deceit, a good deal of reliance is placed on shock, and the emotion generated thereby, provided it is severe enough to still the reflective faculties. There is every reason to suppose that such an emotion would render difficult a consciously planned lie.").

94. Goldman, supra note 39, at 460 (citing Foster, supra note 27, at 315).

95. Hutchins \& Slesinger, supra note 29, at 436-37 (citing Herbert Sidney Langfield, Psychophysical Symptoms of Deception, 15 J. ABNORMAL PSYCHOL. 319, 319-328 (1920-1921); William M. Marston, Reaction-Time Symptoms of Deception, 3 J. EXPERIMENTAL PsYCHOL. 72, 72 $87(1920))$.

96. McFarland, supra note 21, at 917.

97. Boyce, 742 F.3d at 800 (7th Cir. 2014) (Posner, J., concurring).

98. See McGough, supra note 34 , at 488 (in a series of experiments regarding children and fabrication, psychologists concluded that preschoolers told lies to protect their mothers even when the children were not instructed by their mothers or the experimenters what to say or how to act, and "most children inferred guilt from the mother's actions and intuitively lied to protect her").

99. FED. R. EVID. 803 advisory committee's note (although rarely is some other type evidence of the existence of the exciting event not available to corroborate its occurrence, "the only evidence [of the exciting event] may be the content of the statement itself" (citing Armour \& Co. v. Indus. Comm'n, 243 P. 546, 547 (Colo. 1926); Young v. Stewart, 131 S.E. 735, 738 (N.C. 1926))). For the 
excited utterance exception allows for complete fabrication of not only the hearsay statement admitted as an excited utterance, but also of the circumstances that prove a startling event even occurred (thus fulfilling the first requirement - "a startling event"-of the excited utterance exception). Such is the ultimate example of "boot-strapping."

The author imagines a man who legally owns a handgun convicted of felony assault for allegedly threatening his ex-girlfriend with his firearm under the following facts: a frantic declarant telephones the police and shouts that her ex-boyfriend is holding a gun on her and is threatening to shoot her unless she takes him back; the police arrive at the declarant's apartment and she provides a description of her ex-boyfriend, who is arrested a few blocks away as he walks down the sidewalk; police find a loaded handgun in his possession; at trial, the declarant refuses to testify, and the only evidence presented by the prosecutor is the declarant's recorded 911 call (admitted as an excited utterance) and testimony from the police regarding the declarant's condition, her description of the exboyfriend, and details of the ex-boyfriend's arrest. Although the prosecutor asserts that she is not required by the excited utterance exception to produce any corroboration of the exciting event other than the declarant's statement, she argues that possession of the handgun by the defendant when the police arrested him constitutes corroboration of the exciting event (and of the declarant's statement) if the court asks for such. The defendant certainly could be convicted on these facts, especially if the prosecutor explains to the jury that domestic violence victims often refuse to testify against their abusers. However, the

\footnotetext{
general proposition that the excited utterance itself may suffice as the sole proof of the startling event, see, for example, United States v. Brown, 254 F.3d 454, 459 (3d Cir. 2001) ("[T]he generally prevailing rule [is] that an excited utterance may of itself be sufficient to establish the occurrence of the startling event. ... Most jurisdictions also find the statement in itself sufficient." (citing United States v. Moore, 791 F.2d 566, 571 (7th Cir. 1986))). Courts in more recent cases appear hesitant to admit statements when the only evidence of the startling event is the statement itself; courts tend to discuss the lack of a requirement of corroboration but ultimately conclude that - when the statement is ruled admissible - circumstantial evidence of the exciting event did in fact exist. See, e.g., United States v. Arnold, 486 F.3d 177, 202-03 (6th Cir. 2007) (Moore J., dissenting) (arguing that the only evidence of the defendant threatening the declarant with a gun was the statement itself, while the majority concludes that the victim's detailed description of a gun later found in defendant's possession - along with the defendant's demeanor-provided circumstantial evidence of the startling event). However, some courts deny admission of alleged excited utterances without corroboration of the startling event but employ the legal reasoning that nothing in the declarant's statement evinced sufficient personal knowledge required under FED. R. EvID. 602. See, e.g., Gainer v. Wal-Mart Stores E., L.P., 933 F. Supp. 2d 920, 931-32 (E.D. Mich. 2013) (citing Miller v. Keating, 754 F.2d 507 (3d Cir.1985)); Boyd v. City of Oakland, 458 F. Supp. 2d 1015, 1031 (N.D. Cal. 2006) (declarant "was admittedly not present at the alleged event and therefore has no personal knowledge of when it ended. Her assertion is thus inadmissible under FRE 602").
} 
declarant could have fabricated the entire incident, ${ }^{100}$ her knowledge and description of the defendant's handgun coming solely from the period in which they were still together when she presumably could have seen it, held it, or even fired it herself. ${ }^{101}$ Maybe the old adage "bad facts make bad law" reverberates powerfully in this example, but it does appear that the excited utterance exception-especially considering its lack of a requirement of corroboration of the exciting event-could be manipulated via fabrication by some, or many, would-be declarants. ${ }^{102}$

100. See, e.g., Friedman \& McCormack, supra note 25, at 1181. Friedman and McCormack state that:

a call to 911 is likely to lead to a criminal trial (absent a guilty plea), and [] at trial the prosecutor will seek to use the caller's initial statements as evidence, often without the caller testifying in court.... The result is that 911 callers are effectively allowed to testify without exposing themselves to the oath or to cross-examination. Not surprisingly, some callers abuse the opportunity.

Id.

101. Felon-in-possession cases are especially vulnerable to fabricated excited utterances: all the declarant need do is telephone the police and exclaim that the defendant brandished a gun. Regardless whether the defendant ever did brandish a firearm and with no corroboration of the event other than the excited utterance, as long as the defendant is later found in possession of a firearm the arrest and conviction of the defendant is likely assured. See, e.g., United States v. Ballew, $491 \mathrm{~F}$. App'x 589, 591 (6th Cir. 2012) (affirming the proper admission of "he's got a gun" based on "the 911 call, the woman's demeanor, the discovery of a firearm nearby, and the short time frame"); United States v. Holmes, 498 F. App'x 923, 925 (11th Cir. 2012) (affirming that 911 calls were admissible as excited utterances); United States v. Boyd, 237 F. App'x 892 (4th Cir. 2007) ("statements during the 911 call were admissible under the excited utterance exception to the hearsay rule"); Hadley v. United States, Nos. 1:02-CR-147, 1:10-CV-36, 2013 WL 365260, at*1-2 (E.D. Tenn. Jan. 30, 2013) (declarant's statements made during 911 call and when police arrived admissible). In fact, the case that prompted Judge Posner's critique of the excited utterance exception, and thus prompted this Article, is a felon-in-possession case premised on admission of an excited utterance. Boyce, 742 F.3d 792.

102. See, e.g., United States v. DeMarce, 564 F.3d 989, 996 (8th Cir. 2009) (victim's statements to mother inadmissible as excited utterances because victim initially lied to mother); State v. Hansen, 986 P.2d 346, 349 (Idaho Ct. App. 1999) (declarant's "anger with [defendant] could have provided a motivation to fabricate or exaggerate in her description of the events to Officer Nickerson" and therefore statements were inadmissible as excited utterances); People v. Lawler, 568 N.E.2d 895, 900-01 (Ill. 1991) (" $[\mathrm{I}] \mathrm{t}$ is clear that the alleged abduction of the complainant was an event that would qualify as 'sufficiently startling.' However, by the complainant's own admission, she fabricated much of the conversation with her father" and therefore her alleged excited utterances ruled inadmissible); People v. Simon, 953 N.E.2d 1, 24 (Ill. App. Ct. 2011) (declarant-defendant possessed motive to fabricate alleged excited utterance exculpating himself); State v. Brown, 903 P.2d 459, 463 (Wash. 1995) (en banc) (because declarant "decided to lie to the police about being abducted prior to making the 911 call, the call cannot constitute an excited utterance"); Friedman \& McCormack, supra note 25, at 1180 ("if the witness seems sufficiently traumatized by the event, the court may be willing to admit a statement that admittedly includes a self-interested lie"). Of course, the true fear is not all the cases that can be found regarding when a court determined the declarant was lying and thus denied admission of the alleged excited utterance; rather, the true fear is those instances where no court caught the declarant's lie, where a criminal defendant now languishes in prison unjustly, where a civil litigant loses a case when rightfully she should have prevailed, or 


\section{Inaccuracy}

Almost from the birth of the excited utterance exception, psychologists and legal commentators have criticized the notion of assigning reliability to statements uttered by participants or observers after a startling event. ${ }^{103}$ After reviewing early psychological experiments regarding the accuracy of statements made while the declarant labored under emotional stress, Dean Hutchins and Dr. Slesinger opined that, "[o]n psychological grounds, the rule might very well read: Hearsay is inadmissible, especially (not except) if it be a spontaneous exclamation." 104 In essence, for the excited utterance exception to operate as Wigmore envisioned it, a declarant need be so upset by an event that she cannot lie about it but not so upset that she is inaccurate in her description of the event. Imagine the infrequency of scenarios wherein this balancing is actually accomplished.

Therefore, after potential fabrication, the first threat to the credibility of an excited utterance comes from the possibility that the startling event has so unnerved the declarant that her statement is not reliable because it has been negatively affected by the stress from which she is still suffering. ${ }^{105}$ Psychological researchers investigating the effects of stress

where a jury acquits a murderer based on admission into evidence as an excited utterance a fabricated exculpatory statement.

103. See, e.g., Hutchins \& Slesinger, supra note 29, at 437 ("One need not be a psychologist to distrust an observation made under emotional stress," and citing various psychological studies from 1893 through 1927); 2 GeORGE E. DiX ET AL., MCCORMICK ON EVIDENCE $§ 272$ (Kenneth S. Broun ed., 7th ed. 2013) ("While psychologists would probably concede that excitement minimizes the possibility of reflective self-interest influencing the [excited utterance] declarant's statements, they have questioned whether this might be outweighed by the distorting effect of shock and excitement upon the declarant's observation and judgment."); Orenstein, supra note 15, at 180 ("For decades, scholars have attacked the wisdom of fashioning an exception to the hearsay rule that depends upon the excited and stressful state of the speaker."). Psychologists have long criticized the accuracy of excited utterances. See, e.g., Goldman, supra note 39, at 62 ("After considerable study, authorities in the field have found that the accuracy of an individual's perception of an event may vary widely as a result of an infinite number of potential variables." (citing I. Daniel Stewart, Jr., Perception, Memory, and Hearsay: A Criticism of Present Law and the Proposed Federal Rules of Evidence, 1970 UTAH L. REV. 1, 21 (1970))); Moorehead, supra note 21, at 232 ("judicial applications of the exception often appear to overlook the possibility that a traumatic event may not only still reflective thought, but may also hinder rational thought and cognitive functioning").

104. Hutchins \& Slesinger, supra note 29, at 439. They further concluded that "the spontaneous declarations regarded with least favor by the courts are more trustworthy than those which most of them admit without question: those where the trial judge rules that the statement was made under the influence of severe physical shock." Id. at 440; see also Goldman, supra note 39, at 462 ("the more startling the event, and the greater the emotional reaction, the less likely the declarant's observation will be accurate").

105. See Moorehead, supra note 21, at 238-39 (internal citations omitted); see also Goldman, supra note 39, at 459-60 ("[I]t is virtually impossible to ascertain whether the utterance is generated by the episode observed or by operation of the declarant's mental processes, even where the 
on perception and memory have concluded that stress - such as a "startling event" sufficient to satisfy the first requirement of the excited utterance exception-had a negative effect on the accuracy of the declarants such that they accomplished a correct identification only $42 \%$ of the time. ${ }^{106}$ People react differently to stress, but, in general, stressful situations result in the brain releasing more cortisol, and researchers have concluded that increased cortisol levels accompanied by increased heart rate result in both a more defensive reaction and inhibited cognitive functionality. ${ }^{107}$ Given that cortisol levels typically peak anywhere from twenty to forty minutes subsequent to the onset of stress and cortisol impedes memory and recall, ${ }^{108}$ if courts are admitting excited utterances made twenty minutes or more after the event, those statements likely lack accuracy and detail, based purely on elevated cortisol levels.

Whether delving into the psychobiologic processes that affect a declarant's perception and memory of a startling event, or simply approaching it from a layman's perspective, ${ }^{109}$ one can, at a minimum, acknowledge that excited utterances may not be as accurate as statements

declaration is emitted virtually instantaneously upon cognizance of the event. Yet it is the speed which usually forms the crux of the spontaneity requirement." (quoting, Foster, supra note 27, at 325-26)). Moorehead wrote that:

Indeed, stressful events are responsible for problems of perception, cognition, and performance at a variety of levels and in virtually every situation - from a decline in major league batting averages in pressure situations, to the ability of police officers to perform adequately in high-stress training, to the way in which students cope with exam pressure.

Moorehead, supra note 21, at 238-39 (internal citations omitted). Regarding the obsession with potential perjury versus dismissal of any concerns of inaccuracy/misperception based on stress, Orenstein asserted: "the excited utterance doctrine's emphasis on sincerity obfuscates the much more pressing issue of perception and memory. It reflects the disproportionate concern that evidence law evinces for deliberate falsification, as compared with honest error produced by the normal operation of cognitive processes." Orenstein, supra note 15, at 179.

106. Brian H. Bornstein \& Timothy R. Robicheaux, Methodological Issues in the Study of Eyewitness Memory and Arousal, 42 CREIGHTON L. REV. 525, 539 (2009) (basing conclusion on 34 published papers regarding experiments involving over 3,600 participants).

107. See generally Tony W. Buchanan, Daniel Tranel \& Ralph Adolphs, Impaired Memory Retrieval Correlates with Individual Differences in Cortisol Response But Not Autonomic Response, 13 LEARNING \& MEMORY 382 (2006).

108. Margaret E. Kemeny, The Psychobiology of Stress, 12 CURRENT DIRECTIONS IN PSYCHOL. SCI. 124, 126 (2003).

109. Judge Posner wrote, regarding the present sense impression (but such observation is clearly analogous to the excited utterance), that the exception entered American jurisprudence "long before there was a field of cognitive psychology; it has neither a theoretical nor an empirical basis; and it's not even common sense-it's not even good folk psychology." United States v. Boyce, 742 F.3d 792, 801 (7th Cir. 2014) (Posner, J., concurring) (citing Waltz, supra note 27, at 871), cert. denied, 134 S. Ct. 2321 (2014). 
uttered regarding non-stressful events, and, at the extreme, recognize the potential for the severe inaccuracy of an excited utterance. ${ }^{110}$ Though, in some people, stress or arousal can increase accuracy and detail regarding certain perceived information, ${ }^{111}$ how is a court to know whether the declarant is such a person? The psychological literature certainly appears to conclude that, for the majority of individuals, perception and memory are negatively affected by stress such as that caused by a startling event sufficient to meet the threshold requirement of the excited utterance exception. ${ }^{12}$

The second threat to the accuracy of an excited utterance comes from the physical or medical condition of the declarant. The excited utterance exception - whether as defined in the Federal Rules of Evidence, the states' evidence codes, or the states' common law recognition of the exception-requires no analysis of the perceptive qualities and accuracy of the declarant. ${ }^{113}$ Not discussing, or not analyzing, accuracy is not error under the Rules, nor is accuracy a pre-requisite for admissibility, ${ }^{114}$ and this Article does not seek to assign blame to any court for not conducting such an analysis. Case after case exists, however, where it appears there is reason to doubt the accuracy of a declarant's excited utterance, and in such cases the court typically performs no analysis of the declarant's ability to perceive and appreciate the details contained in the statement. ${ }^{115}$

110. See Orenstein, supra note 15, at 181 ("Besides the distracting excitement itself, there may be strong personal feelings evoked by the startling event that affect memory and perception." (citing

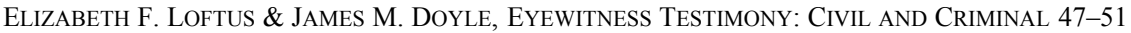
(1987))). Orenstein discusses studies regarding the accuracy of perceptions/memories of persons experiencing natural disasters and studies concluding that "the more violent and emotion-provoking the crime, the less well it will be remembered." Id. at $181 \mathrm{n} .79$ (citing LofTUS \& DoYLE, supra, at $32,51)$.

111. Id. at 182 (citing Howard Egeth, Emotion and the Eyewitness, in THE HEART'S EYE: Emotional Influences in Perception AND AtTEntion 257, 258 (Paula M. Neidenthal \& Shinobu Kitayama eds., 1994)).

112. For a more complete analysis of the psychological arguments both for and against the accuracy of excited utterances, see, for example, Kenneth A. Deffenbacher, The Influence of Arousal on Reliability of Testimony, in EVAluating Witness EVIDENCE: ReCENT Psychological Research And New Perspectives 235-236 (Sally M.A. Lloyd-Bostock \& Brian R. Clifford eds., 1983); JAMES MARSHALL, LAW AND PSYCHOLOGY IN CONFLICT 16 (1966); Stewart, supra note 103, at 21; Egeth, supra note 111.

113. See, e.g., FED. R. EVID. 803(2).

114. See id.

115. E.g., State v. Turner, 420 S.W.3d 666, 667-68 (Mo. Ct. App. 2014) (statements by a declarant who was screaming, crying, bleeding from a head wound, suffering from severe burns to her skin and vocal chords, and, according to a police officer on the scene, "was near death" admitted as excited utterances). A pop cultural reference that may come to mind to prove the effectiveness of cross-examining a witness who otherwise appears to be unbiased, credible, and accurate - as many excited utterance declarants do-is the scene in the Oscar-winning film My Cousin Vinny, wherein 
A recent example is State v. Turner, wherein an excited utterance made by a declarant who was screaming, crying, bleeding from a head wound, suffering from severe burns to her skin and vocal chords, and, according to a police officer on the scene, "was near death," was ruled admissible. ${ }^{116}$ The declarant had been beaten in the face and head, had gasoline poured over her, and had been set on fire. ${ }^{117}$ Subsequent to the excited utterances, the declarant's blood alcohol content was measured by medical personnel as 2.18 , which an expert testified could equate to someone suffering from something as minor as "slurred speech" or as severe as "near coma." 118 The court's analysis focused only on whether the declarant may have had the opportunity for reflective thought such that the statements possibly were fabricated; nowhere in the opinion did the court analyze the potential inaccuracy of the declarant's statements based on her physical or medical condition. ${ }^{119}$ As with so many other courts' analyses, the court in Turner discussed only whether there was a startling event and whether the declarant still suffered from its effect when she made her statements. ${ }^{120}$

Although other hearsay exceptions allow for admission of statements made by declarants who may be impaired - simply because the language of the Rules does not bar such ${ }^{121}$ —only the excited utterance exception is premised upon and, by definition, requires some degree of impairment

the defense lawyer cross-examines an elderly witness regarding her eyewitness identification of the defendants by demonstrating that the witness's eyesight is so poor she could not possibly accurately identify anyone at the subject distance under the subject circumstances. MY COUSIN VINNY (Twentieth Century Fox 1992).

116. Turner, 420 S.W.3d at 667-68. For another recent example of a seemingly impaired declarant, see People v. Anderson, wherein a declarant who had been beaten with a baseball bat, "was bleeding profusely from her head and complaining of dizziness," and was becoming "increasingly agitated," made statements to the police that were admitted as excited utterances without any analysis by the court regarding the potential inaccuracy of the declarant's statements based on her physical or medical condition. 114 A.D.3d 1083, 1085 (N.Y. App. Div. 2014). See also State v. Benavidez, No. 33,480, 2013 WL 5970845, at*11 (N.M. Nov. 7, 2013) (excited utterances of murder victim made shortly before death admitted despite being shot twice and experiencing pain and confusion; court's analysis focused solely on whether declarant had time "for reflection or fabrication"); People v. Bird, No. 2-12-0573, 2013 WL 656827, at *1 (Ill. App. Ct. Feb. 21, 2013) (statements implicating defendant admitted as excited utterances even though 93year-old declarant suffered from dementia and Alzheimer's disease; court performed no analysis of potential effect of declarant's condition on her reliability/accuracy); Mobley v. Kirkpatrick, 778 F. Supp. 2d 291, 308-09 (W.D.N.Y. 2011) (excited utterances admitted even though declarant had "been severely wounded as result of being shot in the back and arm" and was "experiencing extreme pain").

117. Turner, 420 S.W.3d at 668 .

118. Id. at 670 .

119. Id. at 669-71.

120. Id.

121. See FED. R. EVID. 803-04. 
(assuming that an emotional state caused by the stress of a startling event qualifies as impairment). ${ }^{122}$ Of course, it is possible that any hearsay declarant may be impaired, and thus the accuracy of her statement potentially compromised; but courts perform an analysis of the declarant's possible impairment, pursuant to Rules 104 and 602, when determining whether to admit the hearsay statement under a hearsay exception other than under the excited utterance exception. ${ }^{123}$ Whether that impairment emanates from the startling event or from the physical or medical condition from which the declarant may be suffering, the accuracy of statements alleged to be admissible under the excited utterance exception, at a minimum, warrants scrutiny beyond that regarding the fear of fabrication. ${ }^{124}$

\section{THE CONFRONTATION CLAUSE PROBLEM}

Even though properly analyzed and then deemed an admissible excited utterance under Rule 803(2) or the corresponding state evidentiary rule, in criminal prosecutions the hearsay statement must undergo further scrutiny to determine if its admission violates the Sixth Amendment right to confront the witnesses against oneself ${ }^{125}$ in those

122. See FED. R. EvID. 803.

123. See, e.g., United States v. Two Shields, 497 F.3d 789, 793 (8th Cir. 2007) (denying admission of hearsay statement under the statement-against interest, FED. R. EVID. 804 (b)(3), dying declaration, FED. R. EVID. 804 (b)(2), and residual catch-all, FED. R. EVID. 807, exceptions because declarant "highly intoxicated"); Navarrete v. State, 656 S.E.2d 814, 818 (Ga. 2008) (hearsay statement made to medical personnel inadmissible under state's "necessity exception" because declarant was intoxicated), contra, United States v. Water, 413 F.3d 812, 818 (8th Cir. 2005) (hearsay statement of intoxicated declarant admissible as excited utterance because "there was nothing in his demeanor or the circumstances to indicate he had a motive to lie").

124. Other hearsay exceptions recognize that possible impairment of the declarant affects the accuracy, and thus admissibility, of the statement. Regarding the dying declaration exception, see, for example, Charles Nesson, The Evidence or the Event: On Judicial Proof and the Acceptability of Verdicts, 98 HARV. L. REV. 1357, 1374 (1985) ("[T] he reliability of such evidence is obviously overstated. Pain, catastrophic physical calamity, and anguish may characterize the circumstances under which a declarant makes such statements. Perception, memory, comprehension, and clarity of expression are likely to be impaired."). Therefore, under other hearsay exceptions, oftentimes courts analyze the potential impairment of the hearsay declarant. See, e.g., United States v. Jordan, No. Crim. 04-CR-229-B, 2005 WL 513501, at *4 (D. Colo. Mar. 3, 2005) (in murder trial of defendant for stabbing victim to death, district court suppressed dying declaration of victim: "The experience of pain could affect the trustworthiness or accuracy of the declaration" (citing Dying Declarations, 46 Iowa L. REV. 356, 376 (1961))).

125. U.S. CONST. amend. VI. In one of the first cases to cite the Confrontation Clause, Chief Justice John Marshall questioned why the Court should consider admitting any out-of-court statement offered against a criminal defendant: "why a man should have a constitutional claim to be confronted with the witnesses against him, if mere verbal declarations, made in his absence, may be evidence against him." United States v. Burr, 25 F. Cas. 187, 193 (D. Va. 1807). Even by the late 1800 s, however, the Supreme Court still did not specifically relate the issue of hearsay with a 
cases where the declarant does not testify. ${ }^{126}$ Prior to the Supreme Court's landmark case of Crawford v. Washington revising the standard for admissibility of hearsay statements offered against criminal defendants pursuant to the Sixth Amendment's Confrontation Clause, ${ }^{127}$ the prevailing Ohio $v$. Roberts reliability doctrine ${ }^{128}$ allowed greater latitude for admission of excited utterances and other hearsay statements. ${ }^{129}$ Subsequent to Crawford, however, excited utterances and

criminal defendant's Confrontation Clause rights; instead, the Court continued to apply the right to confront only to the prevention of testimony taken ex parte. See, e.g., Mattox v. United States, 156 U.S. 237 (1895) (the word "hearsay" does not even appear in the Mattox opinion). Supreme Court cases from the 1970s refused to extend the Confrontation Clause's protections to evidentiary hearsay. See, e.g., Dutton v. Evans, 400 U.S. 74, 86 (1970) (“[T]his Court has never equated the [Confrontation Clause and evidentiary hearsay], and we decline to do so now." (citing Note, Confrontation and the Hearsay Rule, 75 YALE L.J. 1434, 1436 (1966))); California v. Green, 399 U.S. 149, 155 (1970) (although "hearsay rules and the Confrontation Clause are generally designed to protect similar values ... to suggest that the overlap is complete and that the Confrontation Clause is" a mere extension of the evidentiary rules is simply incorrect). It was only with the advent of Ohio v. Roberts, Idaho v. Wright, and White v. Illinois that the Supreme Court generally began to equate aspects of the rule against hearsay and its exceptions to the right to confrontation guaranteed by the Sixth Amendment. Ohio v. Roberts, 448 U.S. 56, 66 (1980), abrogated by Crawford v. Washington, 541 U.S. 36 (2004); Idaho v. Wright, 497 U.S. 805 (1990); White v. Illinois, 502 U.S. 346 (1992).

126. United States v. Pursley, 577 F.3d 1204, 1223 (10th Cir. 2009) (“[E]ven if a statement qualifies for an exception to the hearsay doctrine- based upon judicially fashioned reliability principles - the statement's admission may violate the Sixth Amendment's mandate for "confrontation' if it constitutes 'testimonial' hearsay." (citing Crawford, 541 U.S. at 61-62)).

127. 541 U.S. at 53-54 (holding that the Sixth Amendment's Confrontation Clause bars "admission of testimonial statements of a witness who did not appear at trial unless he was unavailable to testify and the defendant had had a prior opportunity for cross-examination").

128. See, e.g., Roberts, 448 U.S. at 66 (holding that, to satisfy the Confrontation Clause, an inculpatory hearsay statement by an unavailable declarant offered against a criminal defendant is admissible if it either bears "adequate "indicia of reliability" or falls into a "firmly rooted hearsay exception"); Whorton v. Bockting, 549 U.S. 406, 419 (2007) ("With respect to testimonial out-ofcourt statements, Crawford is more restrictive than was Roberts, and this may improve the accuracy of factfinding in some criminal cases. Specifically, under Roberts, there may have been cases in which courts erroneously determined that testimonial statements were reliable.").

129. Allegations that a criminal defendant's Confrontation Clause rights have been violated typically involve hearsay statements sought to be admitted as excited utterances (or, perhaps, dying declarations). This is because the right to confront is satisfied if the declarant testifies at trial and is cross-examinable; for the most part, crime victims who are non-testifying hearsay declarants are excited utterers and dying declarers, not other types of hearsay exception declarants. Rare is the criminal case where a hearsay exception other than the excited utterance or dying declaration is the hearsay exception involved in a question whether the defendant's constitutional right to confront witnesses was satisfied. However, some courts have erroneously failed to perform a Crawford analysis if the hearsay statement is offered as an excited utterance: "the Pennsylvania Supreme Court has expressly held that Crawford has no application where the trial court admits hearsay testimony pursuant to the excited utterance exception." Wright v. Klopotoski, No. 09-2093, 2010 WL 4321536, at *4 (E.D. Pa. Aug. 30, 2010). Other courts have performed a Crawford analysis when one is not appropriate. See, e.g., Smith v. United States, 26 A.3d 248, 259 (D.C. Cir. 2011) (when criminal defendant seeks to admit exculpatory excited utterance, error for state court to deny admission based on a finding the statement is testimonial under Crawford; the Confrontation Clause applies only when the government seeks to admit hearsay statements by an unavailable declarant). 
other hearsay statements made in response to police questioning asked with the goal of prosecution-or made to persons other than law enforcement but nonetheless with the goal of later prosecution-instead of posed simply to assist law enforcement in addressing an ongoing emergency, were deemed inadmissible due to their testimonial nature. ${ }^{130}$ Crawford's Supreme Court progeny has further refined the admissibility standard of excited utterances and other such hearsay statements that are testimonial in nature. ${ }^{131}$

\section{A. Testimonial}

When a hearsay declarant's statement is made in response to police questioning or in furtherance of later prosecution, the Confrontation Clause may bar its admission if the court determines the statement was testimonial. $^{132}$ John lies sprawled on the floor; Susan rushes to him and

130. In 2007, the Supreme Court confirmed that a criminal defendant's Confrontation Clause rights do not extend to precluding admission of non-testimonial hearsay statements offered against him. Whorton, 549 U.S. at 420 ("Under Crawford ... the Confrontation Clause has no application to [non-testimonial hearsay] statements and therefore permits their admission even if they lack indicia of reliability.").

131. See Davis v. Washington, 547 U.S. 813, 822 (2006) (if "the primary purpose of the interrogation is to establish or prove past events potentially relevant to later criminal prosecution," then the statements are testimonial in nature and thus inadmissible; however, "[s]tatements are nontestimonial when made in the course of police interrogation under circumstances objectively indicating that the primary purpose of the interrogation is to enable police assistance to meet an ongoing emergency"); Michigan v. Bryant, 131 S. Ct. 1143, 1156, 1162 (2011). In Bryant, the Court instructed that correctly categorizing the statement as testimonial or non-testimonial requires:

[a]n objective analysis of the circumstances of an encounter and the statements and actions of the parties to it.... [T] he relevant inquiry is not the subjective or actual purpose of the individuals involved in a particular encounter, but rather the purpose that reasonable participants would have had, as ascertained from the individuals' statements and actions and the circumstances in which the encounter occurred.... [The court] should determine the "primary purpose of the interrogation" by objectively evaluating the statements and actions of the parties to the encounter, in light of the circumstances in which the interrogation occurs.

Id.

132. Davis, 547 U.S. at 822 . The Supreme Court explicitly declined to define "testimonial" in Crawford or subsequent cases; there is considerable debate whether "testimonial" equates only to statements made to law enforcement collected with the goal of prosecution, or to any hearsay statement offered against the criminal defendant, or to something in between. Jeffrey L. Fisherwho argued Crawford before the Supreme Court - and other legal scholars have opined that when a declarant gives a blow-by-blow account of a completed event to someone in a position of authority, the court should categorize the statement as testimonial. Jeffrey L. Fisher, What Happened - and What is Happening - to the Confrontation Clause, 15 J. L. \& POL'Y 587, 624 (2007). Other commentators have argued that "testimonial" means hearsay statements "made in anticipation of prosecutorial use." E.g., Richard D. Friedman, Crawford, Davis, and Way Beyond, 15 J. L. \& POL'Y 
gasps, "What happened?" With his dying breath John exclaims, "Matt shot me!" John's statement incriminating Matt is admissible-via the testimony of Susan recounting the incident on the witness stand at Matt's murder trial - either as an excited utterance or a dying declaration, or both. However, if Susan rushes to help John, who then exclaims, "Tell the police Matt shot me!", that hearsay statement may not be admissible at Matt's murder trial because the court might rule it testimonial-that John uttered it with the intent of assisting in the prosecution of Matt, to serve as a substitute for John's trial testimony. ${ }^{133}$

Similarly, when police question a victim or witness, the circumstances control whether the responses are ruled testimonial or non-testimonial. In Franklin v. Curtin, subsequent to witnessing her father stab to death her mother and two sisters, the surviving four-yearold daughter told police at the crime scene-in the presence of her father just a few feet away - that her father killed her mother and sisters. ${ }^{134}$ The trial court and state appellate court ruled the statement admissible as an excited utterance, but the federal district court held that:

553, 556 (2007). Professor Friedman argued the companion case to Davis, Hammon v. Indiana, 546 U.S. $1088(2006)$.

133. Most courts have become quite adept at the Crawford analysis, scrutinizing hearsay statements in an effort to define them as testimonial or non-testimonial. See, e.g., People v. Castellano, No. 1-08-1709, 2012 WL 6934931, at *5 (Ill. App. Ct. Apr. 23, 2012) (victim's statements to police at murder scene admitted as non-testimonial excited utterances because, "[v]iewed objectively, the nature of what was asked and answered was such that the elicited statements were necessary to be able to resolve an ongoing emergency rather than to simply learn what had happened in the past," but victim's later statements to police in ambulance in response to police question, "again [tell me] what happened," inadmissible because they were testimonial (quoting People v. Sutton, 908 N.E.2d 50, 67 (Ill. 2009))); Best v. United States, 66 A.3d 1013, 1018 (D.C. 2013) (assault victim's excited utterances to police implicating defendant made while she was still in car ruled non-testimonial but statements made moments later after ambulance called and victim sat on curb ruled testimonial). The full excerpt of Best is as follows:

Police, responding to a 9-1-1 call regarding an assault occurring in a car, found Ms. Coleman seated inside, bleeding from her head and face. One officer described her demeanor as "excited, crying, agitated, very emotional, and very, very upset." After summoning an ambulance, Officer Conway asked what had happened. Ms. Coleman gave a brief, but graphic, description of events. The officer then asked her to step out of the car. She did so, and then sat down on the curb. Trying to calm her, Officer Conway asked for more details, which Ms. Coleman provided. "We conclude[d] that the initial statements, recounting the basic facts of the assault, were non-testimonial because the primary purpose of Officer Conway's questioning was to enable him to respond most effectively to an ongoing emergency." "However, we conclude[d] that the more detailed account that Ms. Coleman provided a short time later, after she had alighted from the car and sat down on the curb, was testimonial because at that time the emergency had dissipated."

Best, 66 A.3d at 1018 (quoting Lewis v. United States, 938 A.2d 771, 774, 780 (D.C. Cir. 2007)).

134. No. 07-10548, 2014 WL 1091744, at*7 (E.D. Mich. Mar. 18, 2014). 
[h]er response to the officer was not a cry for help, and it did not enable police officers to end an immediate threat to them or the public. A reasonable participant would have concluded that the primary purpose of the officer's question was to establish what happened, as opposed to ending a present emergency. The Court therefore believes [declarant's] statement to the police was testimonial, and the admission of her statement violated the petitioner's right of confrontation. ${ }^{135}$

Whether Crawford, Davis, Boyce, or the myriad of other excited utterance criminal cases invoking the Confrontation Clause, the advent of recorded 911 telephone calls made to law enforcement has fundamentally changed the manner in which jurors appreciate and consider admission of excited utterances. It is one thing for Officer Jones to testify regarding what the victim told him at the scene of the home invasion, but an entirely separate matter for the jury to hear the victim's own voice on a recorded 911 call frantically recount what just happened to her family and her description of the perpetrators who did it. The excited utterance has become all the more powerful since the declarant's own voice can now be heard. ${ }^{136}$

This heightened constitutional concern to satisfy the Confrontation Clause reserved almost exclusively for the excited utterance exception (and, to a lesser extent, the dying declaration exception) makes the question of admission of such statements in criminal cases that much more critical. Overwhelmingly, it is the admission of excited utterances and not other hearsay exceptions that result in incarceration or execution; in general, defendants are not being convicted with hearsay evidence admitted under the public records exception, or recorded recollection. ${ }^{137}$

\footnotetext{
135. Id. at *2-3, *9.

136. For those familiar with the Harrison Ford-Tommy Lee Jones film The Fugitive, the reaction of jurors while they listen to the murder victim's halting but desperate 911 call for help as she lays in a pool of her own blood provides an example of how the advent of 911 recordings being played during trials has a much greater effect than simple witness accounts of hearsay statements. THE Fugitive (Warner Brothers 1993). [Although real cases are what the law is truly about, rarely do we have visual illustrations for the facts in those real cases; all we have is a cold recitation of the facts provided in the case law. Therefore, imagining the scene via known depictions of similar facts can assist in understanding the legal points attempted to be made in this Article. The author apologizes for the sporadic film references in this Article but hopes they may assist the reader in more fully gleaning the author's intended arguments.].

137. See supra note 4; see also United States v. Boyce, 742 F.3d 792, 799-802 (7th Cir. 2014) (Posner, J., concurring), cert. denied, 134 S. Ct. 2321 (2014) (excited utterance on 911 call "was a major piece of evidence of the defendant's guilt"); Friedman \& McCormack, supra note 25, at 1178 ("Although occasionally other doctrines come into play, the so-called 'excited utterance' or 'spontaneous declaration' exception to the hearsay rule provides the principal basis on which courts allow this type of evidence to bypass the obstacles of the rule against hearsay and the defendant's confrontation right." (internal citations omitted)).
} 
Truly, it is vital that the justice system gets the excited utterance exception right.

\section{B. Non-Testimonial}

The facts in Boyce provide an illustration just how far the Confrontation Clause question has progressed in the ten years since Crawford, considering that neither the majority opinion nor Judge Posner's concurrence even mentions Crawford or performs a testimonial versus non-testimonial analysis: both simply assumed that the declarant Portis's statements to law enforcement on her 911 telephone call were "non-testimonial" and thus not barred by the Confrontation Clause pursuant to Crawford. ${ }^{138}$ The 911 call in Boyce was as follows:

Sarah Portis called 911 at around 7:45 p.m. on March 27, 2010, asking that police come to her residence because her child's father had just hit her and was "going crazy for no reason." The 911 operator asked, "Any weapons involved?" to which Portis responded, "Yes." The operator asked what kind, and Portis said, "A gun." The operator said, "He has a gun?", then "Hello?", and Portis responded, "I, I think so. "Cause he just, he just." After the operator said, "Come on," Portis responded, "Yes!" twice. The operator again inquired, "Did you see one?" and Portis replied, "Yes!" The operator then cautioned Portis that if she wasn't telling the truth, she could be taken to jail. Portis responded, "I'm positive." After giving a description of what Boyce was wearing, the operator asked where he was at the moment. Portis responded that she "just ran upstairs to [her] neighbor's house" and didn't know whether Boyce had left her house yet. ${ }^{1}$

Clearly, the questions the 911 operator $^{140}$ asked Portis were designed to allow the police to meet the ongoing emergency of a possible armed assailant loose on the premises or in the neighborhood, and the answers Portis gave responded only to those questions without adding any potential non-testimonial superfluousness. Neither the majority nor Judge Posner needed to address the Crawford analysis because a decade of case law has evolved to indicate under what scenarios testimonial versus non-testimonial is even a question. ${ }^{141}$

\footnotetext{
138. See Boyce, 742 F.3d at 798-802.

139. Id. at 793 .

140. Such 911 operators are considered "law enforcement" for purposes of the Confrontation Clause. See Davis v. Washington, 547 U.S. 813, 822, 828-29 (2006).

141. However, some courts appear to be extending the non-testimonial limits by admitting excited utterances made to law enforcement that, on their face, appear to be made neither with the goal of allowing the police to meet an ongoing emergency nor for any other purpose than later prosecution. See, e.g., Savoie v. Louisiana State Penitentiary, No. 6:20-1735, 2013 WL 1352021, at
} 
Under Whorton v. Bockting, non-testimonial statements offered against a criminal defendant do not violate the Confrontation Clause and thus are not subject to any greater scrutiny or analysis than were they offered in a civil case or to exculpate the criminal defendant. ${ }^{142}$ In essence, an excited utterance made to someone other than law enforcement may be used to convict a criminal defendant in cases where the statement has no guarantee of trustworthiness other than the fact that it was uttered subsequent to a startling event while the declarant was still under the stress of the startling event. And, excited utterances made to law enforcement that are deemed non-testimonial may be used to convict a criminal defendant even when the statement has no guarantee of trustworthiness other than that it purportedly fit the definition of an excited utterance. It seems the Drafters' intent may have been something more than simply providing the right to confront in cases where an inculpatory excited utterance was made to law enforcement. ${ }^{143}$ Because the excited utterance is by far the most popular exception under which inculpatory hearsay statements are offered against criminal defendants, shouldn't we have a stronger guarantee of trustworthiness than an alleged startling event that produces some stress?

\section{THE REMEDIES}

What is this hold the excited utterance exerts on our evidence law? Really, it all traces back to one man: Wigmore. ${ }^{144}$ His insistence on the accuracy of a statement made while under stress - despite the fallacy of

*2 (W.D. La. Apr. 2, 2013) (statements by 76-six-year-old declarant made to law enforcement at crime scene and in hospital that she was forced to perform oral sex on defendant admitted as excited utterances because police officer "served as more of a comforter to the victim than an interrogating government officer”); Champ v. Zavaras, 431 F. App’x 641, 650-51 (10th Cir. 2011). The Champ court's reasoning is as follows:

Officer Christian arrived upon the scene to find the victim bleeding from her neck. She applied pressure to the wound, and it was necessary for her to ride in the ambulance with the victim to continue to apply pressure to stop the bleeding. Although Officer Christian remained at the hospital with the victim for about two hours, [the victim] was still distressed by the assault and was in a substantial amount of pain from her injuries. [The victim's] statements were not made in a formal setting such as a police station.... Accordingly, we hold that where, as here, a victim makes an excited utterance to a police officer, in a noncustodial setting and without indicia of formality, the statement is nontestimonial interrogation under Crawford.

Champ, 431 F. App'x at 650-51.

142. 549 U.S. 406, 419-20 (2007).

143. See FED. R. EVID. 803(2).

144. See supra note 23 and accompanying text. 
that assertion-is primarily, if not solely, why today we still labor under the admissibility of excited utterances. ${ }^{145}$ Courts are notoriously slow in effecting change. Judge Posner has called for change, along with other jurists and commentators, ${ }^{146}$ but perhaps coming from such a figure as Judge Posner the exception can finally be revised, amended, or discarded. Somewhere, is Wigmore smiling at the consternation he has wrought; his exception still lives today, in the face of reams of court opinions and mountains of psychological evidence undercutting it. What will it take to "reconsider ancient dogmas"147 and allow the excited utterance to go gently into that good night?

\section{A. Judge Posner's Recommendation}

In his concurrence in Boyce, Judge Posner wrote of his desire that "Rule 807 ('Residual Exception') swallow much of Rules 801 through 806."148 In essence, Judge Posner suggests that all hearsay statements sought to be admitted under an exception to the rule against hearsay be analyzed in the same manner as are hearsay statements sought to be admitted when-although they fit within no enumerated hearsay exception - they evince guarantees of trustworthiness and are most probative of the point for which they are offered. ${ }^{149}$ By definition, Rule 807 (the "residual exception") vests in the trial judge tremendous discretion-much more discretion than with any other exception ${ }^{150}$

\footnotetext{
145. See supra notes 24-25 and accompanying text.

146. United States v. Boyce, 742 F.3d 792, 802 (7th Cir. 2014) (Posner, J., concurring) (noting that he is "not alone" in criticizing the exception), cert. denied, 134 S. Ct. 2321 (2014).

147. Id. (Posner, J., concurring).

148. Id. at 802 (Posner, J., concurring) ("Trials would go better with a simpler rule, the core of which would be the proposition ... that hearsay evidence should be admissible when it is reliable, when the jury can understand its strengths and limitations, and when it will materially enhance the likelihood of a correct outcome."). Presumably, Judge Posner would allow an individual admission under Rule 801(d)(2)(A) to remain admissible as non-hearsay. However, by including "Rule 801" in his sentence, one can only surmise that Judge Posner sought to include declarant witnesses' prior statements under Rule 801(d)(1) and statements by party opponents under Rules 801(d)(2)(B) through (E) in his suggested abolition of most enumerated hearsay exceptions in favor of the residual exception swallowing them.
}

149. See id. Legal commenters have made similar-or exactly the same-recommendations as to what Judge Posner proposed. See, e.g., Moorehead, supra note 21, at 243-46 (proposing the res gestae hearsay exceptions - including the excited utterance - be replaced with a residual catch-all); Siegel, supra note 79, at 896 (proposing a "Best Evidence Rule" for hearsay statements); Orenstein, supra note 15, at 164-65, 216 (proposing revising the excited utterance exception, and proposing a new exception for survivors of rape and other sexual violence).

150. See FED. R. Evid. 807. Under the Rules, judges possess a somewhat high degree of discretion in determining whether to admit the testimony of a witness offered as an expert under FED. R. EVID. 702, but this discretion is tempered by the parameters of Daubert and its progeny. Daubert v. Merrell Dow Pharm., Inc., 509 U.S. 579 (1993). 
because admission under it requires no hard and fast criteria be met. ${ }^{151}$ Seemingly aware of the potential inconsistencies and/or abuses by providing such a wide swath of discretion, when debating enactment of the Federal Rules of Evidence, lawmakers admonished judges to exercise extreme caution when deciding whether to admit or reject hearsay statements under the residual exception. ${ }^{152}$

Criticism of the highly discretionary aspect ${ }^{153}$ of the residual exception $^{154}$ began almost as soon as the Rules were enacted. ${ }^{155}$

151. See FED. R. Evid. 807. Rule 807 provides:

(a) In General. Under the following circumstances, a hearsay statement is not excluded by the rule against hearsay even if the statement is not specifically covered by a hearsay exception in Rule 803 or 804 :

(1) the statement has equivalent circumstantial guarantees of trustworthiness;

(2) it is offered as evidence of a material fact;

(3) it is more probative on the point for which it is offered than any other evidence that the proponent can obtain through reasonable efforts; and

(4) admitting it will best serve the purposes of these rules and the interests of justice.

Id.

152. Moorehead, supra note 21, at 243-44 (citing RichARD O. LEMPERT \& STEPHEN A. SAltzburg, A MOdern APPROACH to Evidence 502 (2d ed. 1982)) (although the original advisory committee notes to the first iteration of the residual exception stated that the exception did "not contemplate an unfettered exercise of judicial discretion," the advisory committee notes to the present Rule 807 contain no such warning); S. REP. No. 93-1277 (1974), reprinted in 1974 U.S.C.C.A.N. 7051, 7066. The Supreme Court concluded that the residual exception was not a "firmly rooted" hearsay exception when analyzing Confrontation Clause issues, evincing its suspicion of the use of the exception in criminal cases when offered against the accused. Idaho v. Wright, 497 U.S. 805, 821 (1990).

153. See, e.g., Navedo v. Primecare Med., Inc., No. 1:12-cv-00888, 2014 WL 1451836, at *2 (M.D. Pa. Apr. 14, 2014) ("The decision to exclude evidence offered under the residual hearsay exception of Rule 807 is entrusted to the court's discretion." (citing United States v. Ferri, 778 F.2d 985, 991 (3d Cir. 1985))).

154. When the Federal Rules of Evidence were enacted in 1975, they included a variation of the residual exception within both Rule 803 and Rule 804; however, in 1997, those two residual exceptions-Fed. R. Evid. 803(24) and Fed. R. Evid. 804(b)(5) - were collapsed into the current Rule 807. FED. R. EVID. 807 advisory committee's note.

155. See, e.g., 5 Christopher Mueller \& Laird KirKPatrick, Federal EVIDENCE $§ 8: 139$ (4th ed. 2009), available at Westlaw (last updated May 2014). Mueller and Kirkpatrick explain that:

The House Judiciary Committee proposed to delete the [residual exception] altogether . . . . The accompanying Committee Report reflected the concern that the catchalls inject 'too much uncertainty into the law of evidence' and impair 'the ability of the practitioners to prepare for trial ....' Remarks on the floor of the House reiterated the concern to protect the ability of practitioners to plan for trial, and there were influential critics of the provisions.

Id. (internal citations omitted). The Senate similarly was concerned with the discretion the residual exception bestowed on trial judges, so it proposed - and the House accepted - a notice provision, which allowed the residual exception to escape deletion from the Rules. Id. 
Practicing lawyers desire certainty, or, at least as much certainty as they can negotiate. When preparing to try a case, or deciding whether to try a case or settle/plead, a lawyer wants to know-needs to know-what evidence is most likely to be admitted or excluded. ${ }^{156}$ Definitive rules with detailed requirements provide lawyers that certainty. ${ }^{157}$ The residual exception provides no certainty, instead relying on the trial judge's individual interpretation of the loose verbiage of Rule 807's "equivalent circumstantial guarantees of trustworthiness." 158 That

156. Even when a lawyer sits in her office after interviewing a potential client calculating whether to accept the matter based on her assessment of the strengths and weaknesses of the case and the probability she can admit certain evidence, she needs the certainty of knowing whether hearsay statements uttered in the matter will, most likely, be admitted or rejected.

157. See, e.g., Christopher Mueller, Post-Modern Hearsay Reform: The Importance of Complexity, 76 MinN. L. REV. 367, 397 (1992). Mueller provides that:

Practitioners strongly believe they need protection against broad judicial discretion. They worry that if judges are freed completely from the constraint of rules by the generality of a 'standard,' subject only to the immediate pressures of lawyers and trials, the judges are very likely to err by favoring one or another lawyer or cause without principled basis, not so much because they are venal but because they are human.... Trial judges may need rules of some sort to deal wisely with hearsay. It is one thing for Judge Weinstein, who is both a scholar and an extraordinary jurist, to claim judges work better without rules, and quite another to suppose most judges can do so. Rules also invite a second look by appellate courts, which probably contributes to the development of sound doctrine and corrects some mistakes.

Id. (internal citations omitted).

158. 4 Christopher Mueller \& LAird KirkPatrick, Federal EvidenCe $\S 8: 32$ (4th ed. 2009), available at Westlaw (last updated 2014) (stating that the Supreme Court in Idaho v. Wright noted that the residual exception "invites ad hoc judgments on reliability that do not have behind them the experience and tradition of the categorical exceptions. It is true that the federal [residual exception] in Rule 807 is unbounded in the sense that it lacks specific criteria and could conceivably apply to any statement" (citing Idaho v. Wright, 497 U.S. 805, 816 (1990))); see also State v. Htoo, No. A13-0935, 2014 WL 1758201, at*6 (Minn. Ct. App. May 5, 2014) (reliability of witness recounting hearsay declarant's inculpatory statements offered against criminal defendant is "irrelevant under the residual-hearsay-exception analysis"). As an example of the disparate and highly discretionary approach courts take to the residual exception, consider the recent case of F.T.C. v. Ross, wherein the Fourth Circuit concluded that hearsay statements thoroughly analyzed by the district court under FED. R. EVID. 807 and admitted under the residual exception should not in fact have been admitted under the residual exception. 743 F.3d 886, 893 (4th Cir. 2014). The district court had methodically analyzed each of the enumerated requirements in the Rule and compared those factors to the circumstances surrounding the hearsay statements, ultimately concluding that each of the four elements of the Rule was met. F.T.C. v. Ross, No. RDB-08-3233, 2012 WL 4018037 (D. Md. Sept. 11, 2012). The Fifth Circuit, however, held that the statements were admissible under the exception for adoptive admissions, not under the residual exception. See United States v. Njoku, 737 F.3d 55, 74 (5th Cir. 2013) (declining to overrule district court's "discretionary ruling" refusing to admit exculpatory hearsay statements under the residual exception because they were potentially misleading or confusing, or would require the admission of more evidence for the jury to properly understand them). Different courts employ vastly different tests when determining whether to admit hearsay statements under the residual exception, from the Fifth Circuit's highly restrictive approach to the Ninth Circuit's looser standard. Compare Pozen Inc. v. 
uncertainty may be acceptable in those rare instances where hearsay statements are sought to be admitted under the residual exception, ${ }^{159}$ but to lump all questions of hearsay admissibility into the "analysis" of various trial judges' individual discretion instead of the delineated and detailed analyses provided by Rules 801 through 806 creates far too much uncertainly, such that it may wreak incalculable effects on the

Par Pharm., Inc., 696 F.3d 1151, 1161 n.6 (5th Cir. 2013), with United States v. Fowlie, 24 F.3d 1059, 1069 (9th Cir. 1994), and Draper v. Rosario, No. S-10-32 KJM EFB PC, 2014 WL 1664917, at *4 (E.D. Cal. Apr. 25, 2014). The Fifth Circuit in Pozen provided that:

'The residual hearsay exception is to be used only rarely, in truly exceptional cases.' To admit evidence under the residual hearsay rule, there must be at least circumstantial guarantees of trustworthiness. The Fifth Circuit has found there are equivalent circumstantial guarantees of trustworthiness when the declaration is made under oath and the declarant is subject to the penalties of perjury, the testimony was preserved on videotape, and the witnesses were subject to cross-examination.

696 F.3d at 1161 n.6 (quoting United States v. Walker, 410 F.3d 754, 757-58 (5th Cir. 2005)). In contrast, the Ninth Circuit in Fowlie asserted that: "Hearsay evidence sought to be admitted under [the residual] exception must have circumstantial guarantees of trustworthiness equivalent to the listed exceptions to the hearsay rule." 24 F.3d at 1069 (citing Guam v. Ibanez, 880 F.2d 108, 113 n.5 (9th Cir. 1989)). Along the same lines as the Ninth Circuit, the Eastern District of California explained that, "a district [court] has the discretion to admit a hearsay statement in "exceptional circumstances' so long as it meets [Rule 807]'s requirements." 2014 WL 1664917, at *4 (quoting United States v. Bonds, 608 F.3d 495, 500-01 (9th Cir. 2010)). There are numerous examples wherein it appears the court relied purely on its own discretion in admitting or denying admission of hearsay statements under the residual exception. See, e.g., United States v. Turner, 718 F.3d 226, 233 (3d Cir. 2013) (records of foreign banks admissible under FED. R. EVID. 807 despite not meeting the requirements of FED. R. EVID. 803(6), the business records exception under which domestic bank records are admitted); Gov’t of V.I. v. Mosby, 512 F. App'x 253, 257 (3d Cir. 2013) (proper to deny admission of audio tape under FED. R. EVID. 807 because there was no proof a "hit man" came to the Virgin Islands and committed the murder; defendant had offered an exculpatory recording on which declarant stated to confidential police informant that drug cartel requested he hire a hit man to murder victim in effort to prove defendant did not commit the murder). Because the residual exception is invoked so rarely, some jurisdictions do not even have a reliable body of case law upon which to rely in performing their analyses. E.g., Brumley v. Albert E. Brumley \& Sons, Inc., 727 F.3d 574, 578 (6th Cir. 2013) ("There is a lack of Sixth Circuit case law on the residual exception's trustworthiness requirement outside of the context of the Confrontation Clause. ...").

159. 4 MUELLER \& KIRKPATRICK, supra note 158, at $\S 8: 140$ (noting that Congress desired the residual exception to be "used very rarely, and only in exceptional circumstances." (quoting S. REP. No. 93-1277, supra note 152, at 7066)); see also United States v. Walker, 410 F.3d 754, 757 (5th Cir. 2005) ("The residual hearsay exception "is to be used only rarely, in truly exceptional cases." (quoting United States v. Phillips, 219 F.3d 404, 419 n.23 (5th Cir. 2000)); United States v. Dunford, 148 F.3d 385, 394 (4th Cir. 1998) (the residual exception "should not be construed broadly. To construe it broadly would easily cause the exception to swallow the rule" (citing United States v. Mandel, 591 F.2d 1347, 1368 (4th Cir. 1979), 2 DiX, supra note 73, at § 324)). From April of 2013 to April 2014, there were only eight reported cases from the twelve U.S. courts of appeal involving the question of admissibility of a hearsay statement under Rule 807. To reach these conclusions, the author researched and reviewed cases in the Westlaw database. 
manner in which law is practiced. ${ }^{160}$ We must reserve this highly discretionary rubric of determining whether to admit or reject hearsay for those few instances when an enumerated hearsay exception simply does not fit. If all hearsay were evaluated under the residual exception's parameters, far too much discretion would inure to trial judges. ${ }^{161}$

160. Attorney-client conversations such as the following would become commonplace: "I don't know if I can represent you, sir, because the records you've provided that in essence prove your case might not be admitted into evidence by the trial judge. Historically, such records would have been admitted under what we used to call the 'business records exception,' but some of the judges in this jurisdiction have shown reluctance to admit records such as these, while other judges here have no problem admitting these type records. It all depends on the judge we draw. But I can't take that chance, considering this would be a contingency case and I wouldn't even recover my costs if we lose, all based on the luck of the draw and some judge's personal discretion."

161. As an example of restricting trial judges' discretion in situations where it appears they may have too much, consider criminal sentencing. Based on research concluding there was wide disparity in federal sentencing, in 1984 Congress overwhelmingly passed and President Reagan signed into law the Sentencing Reform Act, following the lead of many states that previously had enacted their own sentencing reform. On both the federal and state levels, judges - armed with near unfettered discretion - had been issuing vastly disparate sentences for essentially the same crimes. Employing a sports analogy, historically every quarter of every basketball game began with a jump ball tip-off, wherein the referee would toss the ball up between two opposing players who would jump and try to tip the ball to a teammate to obtain possession. Additionally, every time during the game that two opposing players had joint possession of the ball, a jump ball tip-off resulted to determine which team would achieve possession. However, during jump ball tip-offs, referees had such a difficult time trying to toss the ball up fairly and completely straight-without inadvertently giving an advantage to either player by tossing the ball closer to him - that the rules were changed. Now, only the beginning of a basketball game commences with a jump ball tip-off; the beginning of each subsequent quarter commences with alternate teams possessing the ball, and every joint possession situation is governed by the alternate possession rule. Because possession of the ball is so important and jump ball tip-offs occur at least four times each game (not including joint possession situations), the rules drafters felt the need to reduce the number of occasions the referee was placed in the position of initiating a jump ball tip-off. The college game was so concerned with this that - unlike high school basketball and professional basketball - the college game simply eliminated quarters and now conducts games in two halves, the first half beginning with a jump ball tip-off and the second half on alternate possession. Like determining whether to admit a hearsay statement under the residual exception, jump ball tip-offs simply are too discretionary-and possession of the ball too important-for the rules drafters to allow jump ball tip-offs to occur too frequently. Similarly, with all deference to Judge Posner (who certainly deserves such, along with the author's immense respect), we must limit, rather than expand, those occasions wherein trial judges are faced with the dilemma of relying almost purely on their individual discretion in determining whether to admit a hearsay statement under the residual exception. Everyone comes from his own perspective, and the author and Judge Posner are no different. As a judge, it appears Judge Posner trusts judges to assess most-if not all-hearsay evidence under the FED. R. EVID. 807's highly-discretionary standard. As a former practicing attorney who tried multi-million dollar cases in federal and state courts, the author desires a less-discretionary rubric for determining the admissibility of hearsay evidence so that lawyers going into a trial know what to expect. We removed the massive discretion judges formerly possessed regarding criminal sentencing, enacting strict sentencing parameters within which judges may exercise some degree of discretion. Justice must be as predictable as possible, both in criminal sentencing and in the admission of hearsay. 


\section{B. The Author's Proposed Remedy}

Now that this Article has beaten up on the residual exception as a means to evaluate and determine the admissibility of all hearsay statements, it will attempt to rehabilitate the residual exception-in revised form - as a means to evaluate and determine admissibility of excited utterances. Obviously there is a reason Rule 807 exists. Certain statements - a very limited few-simply are so reliable that, even though they do not technically fit within the requirements of any of the enumerated exceptions, they nonetheless should be heard and considered by the jury. Recognizing this, prior to the enactment of the Rules, both the states and the federal judiciary employed a form of the residual or catch-all exception. ${ }^{162}$

Were Congress to eliminate the excited utterance exception in the Federal Rules and states do the same, a statement following a startling event that in the past may have been admitted as an excited utterance could be analyzed under a rubric similar to the residual exception, albeit more definitive and detailed such that the exception also encompasses the trustworthiness analysis of the corroboration required under Rule 804(b)(3), the statement against interest exception when the declarant is unavailable. ${ }^{163}$ Whereas Rule 807 , the residual exception, allows trial judges wide latitude in assessing the trustworthiness of hearsay statements offered under the exception and does not require the declarant be unavailable to testify, ${ }^{164}$ hearsay statements offered under Rule 804(b)(3) not only require the declarant be unavailable, ${ }^{165}$ but the

162. The exception as we now know it traces back to the famous 1961 Dallas County $v$. Commercial Union Assurance Co. case, the first reported case wherein a court admitted a hearsay statement under what we now call the residual exception. 286 F.2d 388 (5th Cir. 1961). The opinion teemed with judicial and legal lions: Judge John Minor Wisdom of the Fifth Circuit wrote the opinion-cobbling together rationales employed by Judge Learned Hand and Professor Wigmore - approving the admission of a 1901 newspaper article describing an alternate cause for the alleged damage to the subject property, based on reliability, necessity, and "common sense," despite the evidence's failure to fall within the ancient documents exception, the business records exception, or "any other readily identifiable and happily tagged species of hearsay exception." Id. at 397-98. As Judge Wisdom reasoned, why would a newspaper reporter in 1901 lie about a 1901 courthouse fire? Id. at 397. Did the reporter magically know that nearly 60 years later the courthouse would collapse and there would be a lawsuit regarding who should pay for the damages, and therefore the reporter fabricated the newspaper article in 1901 to protect the 1957 insurance company from having to pay on the policy? See id. Common sense tells us that the 1901 newspaper article possesses a high degree of reliability. See id.

163. FED. R. EVID. 804(b)(3).

164. FED. R. EVID. 807.

165. FED. R. EVID. 804(b)(3). 
advisory committee notes detail six trustworthiness factors. ${ }^{166}$ If, in situations where a hearsay statement is sought to be admitted under the former excited utterance exception, an unavailable hearsay declarant's statement is analyzed employing a hybrid of the Rule 807 residual exception's trustworthiness factors ${ }^{167}$ and the Rule 804(b)(3) statement against interest's trustworthiness factors, along with a new factor to address the potential inaccuracies of an impaired declarant's excited utterance, the system could ensure that these especially vital hearsay statements are properly scrutinized before admission into evidence.

Thus, this Article proposes abolishing Rule 803(2), the excited utterance exception, and creating the following hearsay exception as Rule 804(b)(7):

Statement Immediately Subsequent to Startling Event or Condition. A statement made immediately subsequent to a startling event or condition that is supported by corroborating circumstances that clearly indicate its trustworthiness. ${ }^{168}$

166. AdVISORY COMMITTEE ON EVIDENCE RULES, REPORT OF THE AdVISORY COMMITTEE ON EVIDENCE RULES 23 (2002). The factors provided by the committee are:

(1) the timing and circumstances under which the statement was made;

(2) the declarant's motive in making the statement and whether there was a reason for the declarant to lie;

(3) whether the declarant repeated the statement and did so consistently, even under different circumstances;

(4) the party or parties to whom the statement was made;

(5) the relationship between the declarant and the opponent of the evidence; and

(6) the nature and strength of independent evidence relevant to the conduct in question.

Id. Although the Rule was not enacted in 2002, in 2010 a similar rule was enacted.

167. The factors that have been identified in determining trustworthiness are: (1) the age, education, and experience of the declarant; (2) the personal knowledge of the declarant regarding the subject matter of the statement; (3) the oral or written nature of the statement; (4) the ambiguity of the statement; (5) the consistency with which the statement is repeated (perhaps even in varying situations); (6) the time lapse between the event and the making of the statement; (7) the partiality of the declarant and the relationship between the declarant and the witness; (8) the declarant's motive to speak truthfully or untruthfully; (9) the spontaneity of the statement, as opposed to responding to leading questions; (10) the making of the statement under oath; (11) the declarant being subject to cross-examination at the time the statement was made; and, (12) the recantation or repudiation of the statement after it was made. See, e.g., Aamco Transmissions, Inc. v. Baker, 591 F. Supp. 2d 788, 799 (E.D. Pa. 2008).

168. Requiring the declarant be unavailable emphasizes the preference for in-court, crossexaminable testimony before the trier of fact to determine credibility and weight. Under this new rule, only in those cases where the declarant is unavailable would a former "excited utterance" be admissible. 
Requiring the statement be made "immediately" subsequent to the event or condition allows trial judges discretion in determining "how long is too long" while providing guidance: one day after the event clearly is not "immediately subsequent" but perhaps, under the individual circumstances, thirty minutes may be considered "immediately subsequent." The advisory committee notes accompanying the rule should include a list of trustworthiness factors that the trial judge must evaluate prior to ruling on the admissibility of the statement. Such factors should be: (1) the age, education, and experience of the declarant; (2) the personal knowledge of the declarant regarding the subject matter of the statement; (3) the physical, mental, and emotional state of the declarant at the time the statement was made; (4) the timing and circumstances under which the statement was made; (5) the declarant's motive in making the statement and whether there was a reason for the declarant to lie; (6) the ambiguity of the statement; (7) the time lapse between the event and the making of the statement; (8) the partiality of the declarant and the relationship between the declarant and the witness; (9) the spontaneity of the statement, as opposed to responding to leading questions; (10) whether the declarant repeated the statement and did so consistently, even under different circumstances; (11) the relationship between the declarant and the opponent of the evidence; (12) the recantation or repudiation of the statement after it was made; and, (13) the nature and strength of independent evidence relevant to the conduct in question. Twelve of these thirteen factors are an amalgamation of the trustworthiness factors included in the advisory committee notes accompanying Rules 804(b)(3) and 807. ${ }^{169}$ The third enumerated factor is created to address the risk of inaccuracy based on the state/condition of the declarant. Enumerated factors five, eight, and eleven specifically address the traditional concern of fabrication/perjury.

\section{CONCLUSION}

Judge Posner rightfully criticized the excited utterance exception, based on the psychological data and the other risks this Article has examined; however, the call to abolish all hearsay exceptions contained in Rules 801 through 806 and simply transfer them into the residual catch-all does not appear to be the best solution, at least for the excited utterance. There is a reason this exception exists, but its utility and

169. See FED. R. Evid. 804(b)(3); AdVISORY COMmitTEE On EvidenCE Rules, supra note 166, at 23 . 
reliability are highly suspect under its current iteration. Eliminating Rule 803(2) and creating Rule 804(b)(7) would address the concerns expressed by Judge Posner and legal commentators while providing for the admissibility of those statements we should and do trust. Professor Wigmore may not agree, but it's time we abolish the excited utterance exception as currently written and applied in favor of a more detailed, more reliable exception. 